Benchmarking Non-Hardware Balance of System (Soft) Costs for U.S. Photovoltaic Systems Using a Data-Driven Analysis from PV Installer Survey Results 


\section{Benchmarking Non-Hardware Balance of System (Soft) Costs for U.S. Photovoltaic Systems Using a Data-Driven Analysis from PV Installer Survey Results}

Kristen Ardani', Galen Barbose², Robert Margolis', Ryan Wiser², David Feldman', and Sean Ong ${ }^{1}$

\footnotetext{
${ }^{1}$ National Renewable Energy Laboratory

${ }^{2}$ Lawrence Berkeley National Laboratory
}

NREL is a national laboratory of the U.S. Department of Energy, Office of Energy Efficiency and Renewable Energy, operated by the Alliance for Sustainable Energy, LLC. Contract No. DE-AC36-08G028308

LBNL's work was supported by the U.S. Department of Energy SunShot program under Contract No. DE-ACO2-05CH11231

Technical Report DOE/GO-10212-3834 • November 2012

National Renewable Energy Laboratory 15013 Denver West Parkway Golden, CO 80401

303-275-3000 • www.nrel.gov
Lawrence Berkeley National Laboratory 1 Cyclotron Road Berkeley, CA 94720

510-486-4000 • www.lbnl.gov 


\section{NOTICE}

This report was prepared as an account of work sponsored by an agency of the United States government. Neither the United States government nor any agency thereof, nor any of their employees, makes any warranty, express or implied, or assumes any legal liability or responsibility for the accuracy, completeness, or usefulness of any information, apparatus, product, or process disclosed, or represents that its use would not infringe privately owned rights. Reference herein to any specific commercial product, process, or service by trade name, trademark, manufacturer, or otherwise does not necessarily constitute or imply its endorsement, recommendation, or favoring by the United States government or any agency thereof. The views and opinions of authors expressed herein do not necessarily state or reflect those of the United States government or any agency thereof.

Available electronically at http://www.osti.gov/bridge

Available for a processing fee to U.S. Department of Energy and its contractors, in paper, from:

U.S. Department of Energy

Office of Scientific and Technical Information

P.O. Box 62

Oak Ridge, TN 37831-0062

phone: 865.576 .8401

fax: 865.576.5728

email: mailto:reports@adonis.osti.gov

Available for sale to the public, in paper, from:

U.S. Department of Commerce

National Technical Information Service

5285 Port Royal Road

Springfield, VA 22161

phone: 800.553 .6847

fax: 703.605.6900

email: orders@ntis.fedworld.gov

online ordering: http://www.ntis.gov/help/ordermethods.aspx 


\section{Acknowledgments}

The authors would like to thank the following individuals and organizations for their contributions to and review of this work: David Arfin (First Energy Finance), Jennifer DeCesaro (U.S. Department of Energy Solar Energy Technologies Program [SETP]), Alan Goodrich (National Renewable Energy Laboratory [NREL]), Ted James (NREL), David McFeely (SolarTech), Jesse Morris (Rocky Mountain Institute), Joachim Seel (Lawrence Berkeley National Laboratory), Rachel Tronstein (SETP), Sarah Truitt (NREL), SolarTech, and Jarett Zuboy (consultant). 


\section{Executive Summary}

This report presents results from the first U.S. Department of Energy (DOE) sponsored, bottomup data-collection and analysis of non-hardware balance-of-system costs - often referred to as "business process" or "soft" costs-for residential and commercial photovoltaic (PV) systems. Annual expenditure and labor-hour-productivity data are analyzed to benchmark 2010 soft costs related to the DOE priority areas of (1) customer acquisition; (2) permitting, inspection, and interconnection; (3) installation labor; and (4) installer labor for arranging third-party financing. Annual expenditure and labor-hour data were collected from 87 PV installers. After eliminating outliers, the survey sample consists of 75 installers, representing approximately $13 \%$ of all residential PV installations and 4\% of all commercial installations added in 2010.

Including assumed permitting fees, in 2010 the average soft costs benchmarked in this analysis total $\$ 1.50 / \mathrm{W}$ for residential systems (ranging from $\$ 0.66 / \mathrm{W}$ to $\$ 1.66 / \mathrm{W}$ between the $20^{\text {th }}$ and $80^{\text {th }}$ percentiles). For commercial systems, the median 2010 benchmarked soft costs (including assumed permitting fees) are $\$ 0.99 / \mathrm{W}$ for systems smaller than $250 \mathrm{~kW}$ (ranging from $\$ 0.51 / \mathrm{W}$ to $\$ 1.45 / \mathrm{W}$ between the $20^{\text {th }}$ and $80^{\text {th }}$ percentiles) and $\$ 0.25 / \mathrm{W}$ for systems larger than $250 \mathrm{~kW}$ (ranging from $\$ 0.17 / \mathrm{W}$ to $\$ 0.78 / \mathrm{W}$ between the $20^{\text {th }}$ and $80^{\text {th }}$ percentiles). Additional soft costs not benchmarked in the present analysis (e.g., installer profit, overhead, financing, and contracting) are significant and would add to these figures. The survey results provide a benchmark for measuring - and helping to accelerate - progress over the next decade toward achieving the DOE SunShot Initiative's soft-cost-reduction targets.

We conclude that the selected non-hardware business processes add considerable cost to U.S. PV systems, constituting 23\% of residential PV system price, $17 \%$ of small commercial system price, and $5 \%$ of large commercial system price (in 2010). These processes present significant opportunities for further cost reductions and labor-productivity gains. 


\section{Table of Contents}

Acknowledgments ......................................................................................................................... ii

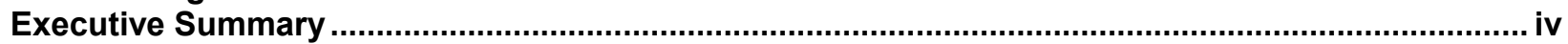

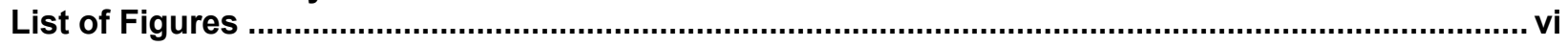

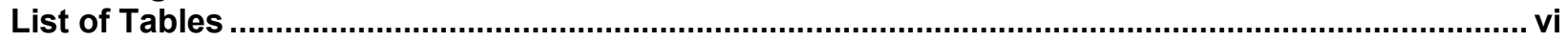

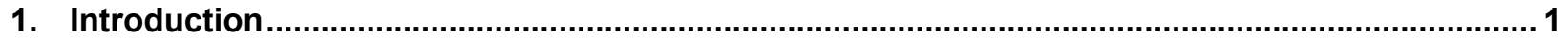

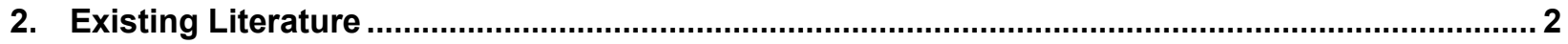

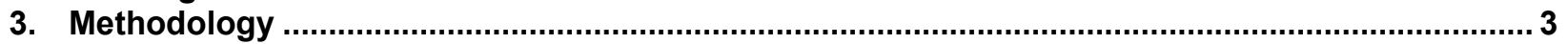

4. Residential PV System Data Collection and Results ............................................................. 4

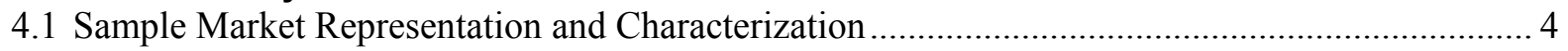

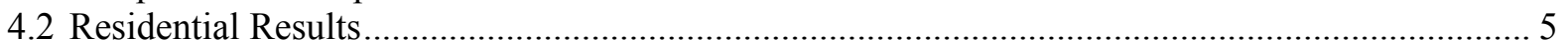

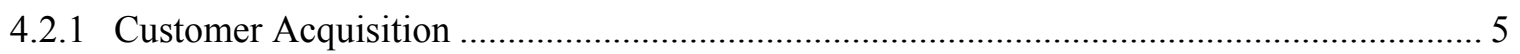

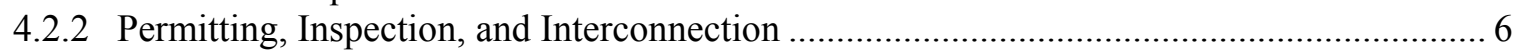

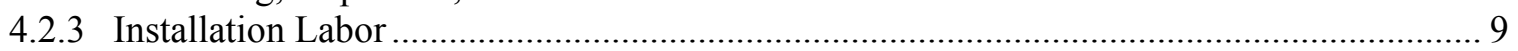

4.2.4 Installer Labor for Arranging Third-Party Financing ................................................... 9

5. Commercial PV System Data Collection and Results................................................................ 11

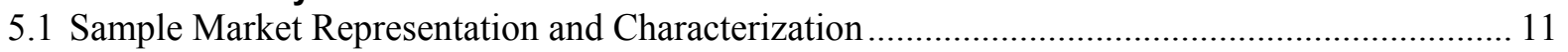

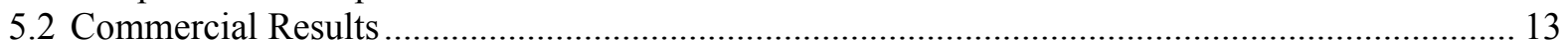

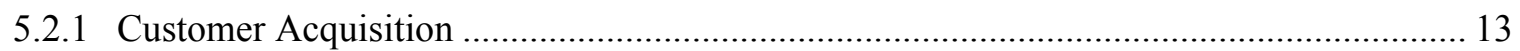

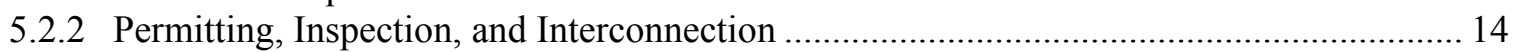

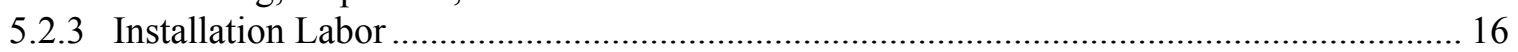

5.2.4 Installer Labor for Arranging Third-Party Financing .................................................. 17

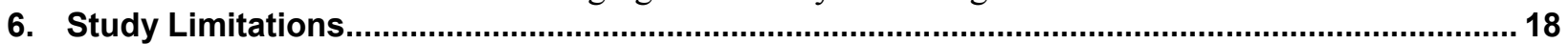

7. Summary of Survey Results ........................................................................................................ 18

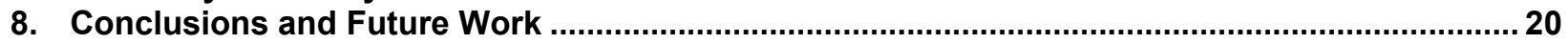

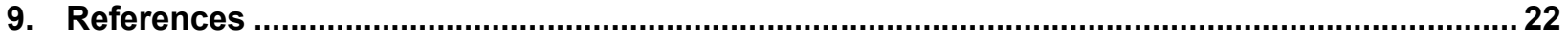

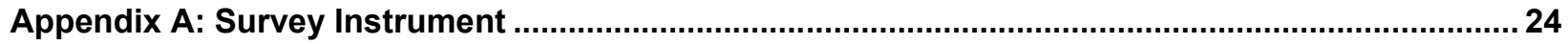




\section{List of Figures}

Figure 1. Reported customer-acquisition costs for each residential installer surveyed ....................6

Figure 2. Total permitting, inspection, and interconnection labor-hour requirements per

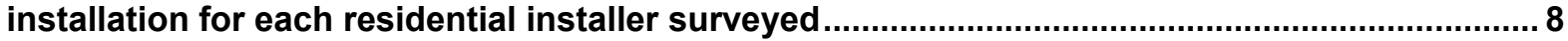

Figure 3. Hours per installation for permitting, inspection, and interconnection.............................. 8

Figure 4. Total installation labor requirements by residential system size ..................................... 9

Figure 5. Residential PV system financing structure, by installer volume ....................................... 10

Figure 6. Number of commercial PV systems installed in 2010 by survey respondents ..................12

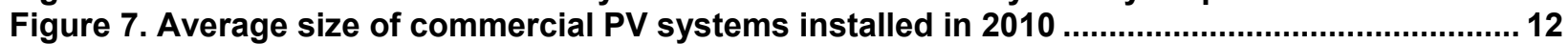

Figure 8. Median customer-acquisition costs for commercial PV installers .................................... 14

Figure 9. Reported customer-acquisition costs for each commercial installer surveyed ................ 14

Figure 10. Hours per commercial installation for permitting, inspection, and interconnection,

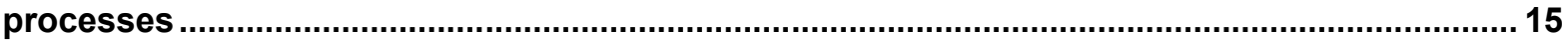

Figure 11. Median permitting, inspection, and interconnection labor costs for commercial PV

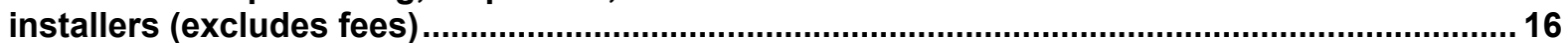

Figure 12. Median installation labor costs for commercial PV installers........................................ 17

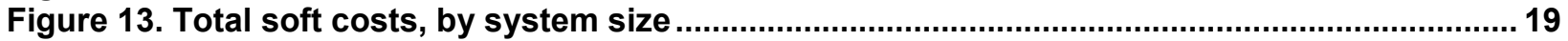

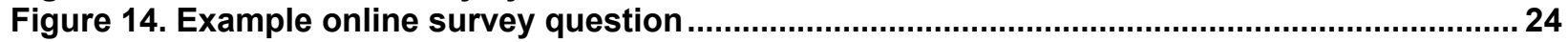

\section{List of Tables}

Table 1. Labor class and wage assumptions used to calculate labor costs ................................... 4

Table 2. Cleaned residential sample market representation .............................................................. 5

Table 3. Customer-acquisition costs for residential PV installers ............................................... 6

Table 4. Average total residential permitting, inspection, and interconnection costs ...................... 7

Table 5. Summary of selected residential and commercial PV system soft costs (2010)................ 20 


\section{Introduction}

The global average wholesale price for photovoltaic (PV) modules fell from $\$ 4.04$ per watt (W) in 2005 to $\$ 2.40 / \mathrm{W}$ in 2010 , while the capacity-weighted average of residential and commercial U.S. PV system prices declined from $\$ 7.90 / \mathrm{W}$ to $\$ 6.20 / \mathrm{W}$ over the same period (Barbose et al. 2011). Thus, the reduction in module price accounted for the vast majority of the total decline in average installed PV system price from 2005 to 2010. Consequently, non-module hardware and non-hardware costs have accounted for a significant, and increasing, portion of average installed PV system prices in the United States (Barbose et al. 2011). To track and analyze the rapidly evolving price structures of PV systems, a thorough understanding of non-module cost components is needed.

To date, a number of analyses have examined non-module PV system hardware costs, including the costs of power electronics and other balance-of-system (BOS) hardware elements. Several other analysts have examined non-hardware BOS costs - often referred to as "business process" or "soft" costs - which include permitting and commissioning, profit, overhead, installation labor, customer acquisition, and financing. Goodrich et al. (2012), for example, estimate that total soft costs constituted, on average, $47 \%$ of U.S. installed residential PV system price and $33 \%$ of installed commercial system price in 2010, with variation around this average based on system size, location, and other factors. ${ }^{1}$ Some analysts have published details about individual soft-cost elements, and others have produced results that are available by subscription only.

A survey data-driven, bottom-up examination of soft costs for residential and commercial PV systems, with granularity into multiple individual cost components, has not been published to date. The purpose of this analysis, therefore, is to provide further granularity to total soft-cost estimates and quantify specific and previously unmeasured soft costs for residential and commercial PV systems. Unlike PV hardware costs, which can be readily benchmarked with data collected from equipment manufacturers and purchasers (and for which a variety of available indexes already exist), quantifying soft costs requires detailed tracking of the time and resources required to complete the various stages of a PV system sale and installation. To quantify key soft costs, we fielded a survey of U.S. PV installers that collected data on the labor hours required, per installation, to complete discrete stages of the PV business process, along with data on annual expenditures for customer acquisition. Similar to Goodrich et al. (2012), we translate labor-hour requirements per installation into dollars per watt using system size, labor class and composition assumptions, and fully burdened wages. ${ }^{2}$

Our survey data and analysis focus on soft costs related to the U.S. Department of Energy (DOE) priority areas of (1) customer acquisition; (2) permitting, inspection, and interconnection (PII); (3) installation labor; and (4) installer labor for arranging third-party financing. Other soft costs and end-consumer price components not benchmarked by this analysis-including installer

\footnotetext{
${ }^{1}$ Goodrich et al. (2012) benchmark installed system price using the overnight capital cost, or cash purchase price, for a system installed in the second half of 2010 (the period for which cost data underlying the model were provided). Financing costs are not considered.

${ }^{2}$ Burdened labor rates include worker's compensation insurance, $6.4 \%$; federal and state unemployment insurance, 6.2\%; Social Security taxes (FICA), 7.65\%; builder's insurance, $0.44 \%$; and public liability insurance, $2.02 \%$ (RSMeans 2010).
} 
profit, overhead, financing, and contracting - contribute significantly to system prices and represent areas for further study.

The average 2010 soft costs benchmarked in this analysis total $\$ 1.50 / \mathrm{W}$ for residential systems (ranging from $\$ 0.66 / \mathrm{W}$ to $\$ 1.66 / \mathrm{W}$ between the $20^{\text {th }}$ and $80^{\text {th }}$ percentiles). For commercial systems, the median 2010 benchmarked soft costs are $\$ 0.99 / \mathrm{W}$ for systems smaller than $250 \mathrm{~kW}$ (ranging from $\$ 0.51 / \mathrm{W}$ to $\$ 1.45 / \mathrm{W}$ between the $20^{\text {th }}$ and $80^{\text {th }}$ percentiles) and $\$ 0.25 / \mathrm{W}$ for systems larger than $250 \mathrm{~kW}$ (ranging from $\$ 0.17 / \mathrm{W}$ to $\$ 0.78 / \mathrm{W}$ between the $20^{\text {th }}$ and $80^{\text {th }}$ percentiles).

The DOE SunShot Initiative aims to reduce the installed-system price contribution of all soft costs to approximately $\$ 0.65 / \mathrm{W}$ for residential systems and $\$ 0.44 / \mathrm{W}$ for commercial systems by 2020 (DOE 2012). ${ }^{3}$ Our results provide a partial benchmark for measuring progress over the next decade toward achieving these total soft-cost targets - and inform strategies for accelerating softcost reductions.

The remainder of this report is structured as follows. Section 2 briefly describes the existing softcost literature. Section 3 describes the survey and analysis methodology we used. Section 4 describes the residential PV system data collection and results, and Section 5 does the same for commercial PV systems. Section 6 discusses the study's limitations. Section 7 summarizes the results, and Section 8 draws conclusions and outlines areas for potential future work. Appendix A contains our installer survey instrument.

\section{Existing Literature}

Most existing literature on the non-hardware elements of PV installations discusses how bureaucratic hurdles and permitting paperwork requirements impede the large-scale deployment of, and add considerable cost to, U.S. PV systems but does not address the broader set of soft costs that increase the price of residential and commercial PV systems (Brooks 2011, Rose et al. 2011, Varnado and Sheehan 2009, Pitt 2008). A Sierra Club study reports permitting fees across jurisdictions, gathered through an ongoing survey process (Mills and Newick 2011). While this work discusses the wide variation in fees for residential and commercial PV systems, it is limited in geographic scope to California. The non-profit organization Vote Solar has expanded on these California fee data to include permitting information across approximately 20 states, and it has published the data online through its Project Permit initiative (Vote Solar 2011). Although the Sierra Club and Vote Solar have successfully drawn attention to the need to harmonize permitting requirements and reduce fees across jurisdictions, their efforts have not sought to benchmark the broader set of soft costs, beyond permitting fees, in a bottom-up manner.

The Rocky Mountain Institute (RMI) has analyzed BOS costs, including soft costs, with a focus on commercial and utility-scale systems of up to $20 \mathrm{MW}$ capacity (Bony et al. 2010). The RMI report, based on a charrette of 50 industry stakeholders, estimates that soft costs for a "typical large installation" were $\$ 0.39 / \mathrm{W}$ in 2010 . The PV installer Sun Run also has analyzed selected soft costs (Sun Run 2011). Data for installer expenditures on the various stages of the permitting

\footnotetext{
${ }^{3}$ The SunShot Initiative's total installed price targets are $\$ 1.50 / \mathrm{W}$ for residential systems and $\$ 1.25 / \mathrm{W}$ for commercial systems.
} 
and inspection process, as well as additional marketing and advertising costs due to cancellations and reduced customer referrals, were collected from 15 residential PV installers through in-depth interviews. The report concludes that these costs can add up to $\$ 2,516$ per installation, or up to $\$ 0.50 / \mathrm{W}$, for a 5-kW system (Sun Run 2011). Additional efforts to estimate soft costs are available, via subscription, from Photon Consulting, Bloomberg New Energy Finance, and other consulting organizations.

While the body of work examining soft costs is relatively small, more comprehensive literature exists on PV system price. ${ }^{4}$ For example, Lawrence Berkeley National Laboratory (LBNL) has produced a series of reports aggregating historical price data sourced primarily from state and utility PV incentive programs, such as the California Solar Initiative (Barbose et al. 2011). Although the LBNL analysis presents variability in PV system prices attributed to a wide range of factors - such as state, system size, ownership structure, technology, and efficiency - because of the top-down nature of the market-price data used, it is not possible to identify componentlevel costs beyond the broad categories of module, inverter, and other. ${ }^{5}$ In contrast, Goodrich et al. (2012) use a bottom-up modeling methodology to benchmark PV system prices and report detailed component costs such as installation materials, electrical labor, installation labor, supply chain costs, permitting and commissioning, and installer overhead. Although this work is among the most granular available in the existing literature, soft costs remain relatively aggregated. The aim of our analysis is to disaggregate the soft costs further and provide benchmarks for progress toward the SunShot Initiative's soft-cost targets.

In summary, no thorough, bottom-up examination of soft costs for residential and commercial PV systems, with a high level of granularity into multiple individual components, has been published publicly. This report partially fills this gap in the literature by presenting results from a survey of residential and commercial PV installers, focusing on a large, but not exhaustive, subset of PV soft costs.

\section{Methodology}

In collaboration with SolarTech, a nonprofit public-private consortium dedicated to streamlining the PV installation process, we disseminated an 18-question online survey to SolarTech's network of more than 300 U.S. residential and commercial PV installers to benchmark the average time and cost of business processes for PV systems installed in 2010. Appendix A shows the complete survey instrument. Data on labor hours per installation were collected for the areas of PII, installer arrangement of third-party financing, and installation. Reported average labor hours per installation were translated into cost per watt using assumptions about system size, labor class and proportional share of labor, and fully burdened labor rates. Table 1 depicts the labor class, share of labor, and wage assumptions used to calculate total labor costs for each softcost category (U.S. Bureau of Labor Statistics 2011). In addition, total annual expenditure data were collected for customer-acquisition costs in three categories: marketing and advertising, system design, and all other customer-acquisition costs. ${ }^{6}$ Annual expenditures were translated

\footnotetext{
4 "Price" here means the price paid by the end user.

${ }^{5}$ Barbose et al. (2011) use the category "other" to capture all costs other than module and inverter costs.

6 "All other customer acquisition costs" include sales calls, site visits, travel time to and from the site, contract negotiation with the system host/owner, and bid/pro-forma preparation but exclude marketing/advertising and system design.
} 
into dollars per watt, for each cost category, based on the reported number of installations and PV system size.

Table 1. Labor class and wage assumptions used to calculate labor costs

\begin{tabular}{|c|c|c|c|}
\hline Soft Cost Category & Occupation (labor class) & Share of Labor Used (\%) & $\begin{array}{l}\text { Burdened } \\
\text { Wage }(\$ / h)\end{array}$ \\
\hline \multirow{2}{*}{ Permit preparation } & Permit procurement & 70 & 36.69 \\
\hline & Administrative staff & 30 & 19.56 \\
\hline \multirow{2}{*}{ Permit submission } & Permit procurement & 30 & 36.69 \\
\hline & Administrative staff & 70 & 19.56 \\
\hline \multirow{2}{*}{ Inspection } & Installer (roofer) & 70 & 40.49 \\
\hline & Administrative staff & 30 & 19.56 \\
\hline \multirow{2}{*}{ Interconnection } & Permit procurement & 30 & 36.69 \\
\hline & Administrative staff & 70 & 19.56 \\
\hline \multirow{2}{*}{ Installation } & Electrician & \multirow{2}{*}{ As reported by installer } & 60.12 \\
\hline & Installer (roofer) & & 40.49 \\
\hline \multirow{2}{*}{$\begin{array}{l}\text { Incentive application } \\
\text { process }\end{array}$} & Installer (roofer) & 30 & 40.49 \\
\hline & Administrative staff & 70 & 19.56 \\
\hline $\begin{array}{l}\text { Installer labor associated } \\
\text { with third-party financing }\end{array}$ & Financial analyst & 100 & 50.75 \\
\hline
\end{tabular}

\section{Residential PV System Data Collection and Results}

\subsection{Sample Market Representation and Characterization}

A raw sample of 70 residential PV installers, representing $18 \%$ of added U.S. residential installations in 2010, was cleaned for outliers on a per-question basis by eliminating the highest $5 \%$ and lowest $5 \%$ of cost-per-watt values and erroneous responses. The cleaned sample sizes range by cost category from 47 to 60 and represent between $10 \%$ and $16 \%$ of added U.S. residential PV installations in 2010 (Table 2). The sample is predominately composed of westcoast, small-volume installers, with only 18 of the 70 respondents completing more than 100 installations in 2010. The four largest-volume installers in the sample combined to complete 4,315 installations, approximately $50 \%$ of the total number of systems in the sample. 
Table 2. Cleaned residential sample market representation

\begin{tabular}{|l|c|c|c|}
\hline \multicolumn{1}{|c|}{ Cost Category } & Sample Size & $\begin{array}{c}\text { Number of } \\
\text { Installations }\end{array}$ & $\begin{array}{c}\text { U.S. Residential PV } \\
\text { Additions, 2010 (\%) }\end{array}$ \\
\hline Other customer acquisition & 47 & 6,197 & 13 \\
\hline System design & 48 & 4,601 & 10 \\
\hline Marketing/advertising & 47 & 6,197 & 13 \\
\hline Permitting, inspection, interconnection labor & 60 & 6,897 & 14 \\
\hline Applying for/receiving incentives & 60 & 6,726 & 14 \\
\hline Installation labor & 56 & 6,038 & 13 \\
\hline Installer labor associated with third-party financing & 60 & 7,882 & 16 \\
\hline
\end{tabular}

\subsection{Residential Results}

We assume an average system size of $5 \mathrm{~kW}$ when calculating cost per watt for all soft-cost categories examined at the residential scale, except installation labor. For installation labor, we calculate cost per watt for each installer using that installer's reported average system size; we assume installation-labor costs for residential systems scale with system size, while the other soft costs measured do not. The residential survey results are reported below in terms of the average cost per watt, across respondents, weighted by total number of installations per respondent.

\subsubsection{Customer Acquisition}

Customer-acquisition activities can add considerable time and cost to PV installations, perhaps especially in states with less-mature markets where perceived technology risk and unfamiliarity with PV might increase bid-failure rates. Expenses related to customer acquisition — such as lead generation, bid and pro-forma preparation, contract negotiation, and system design - increase sunk costs to the installer. The survey asked installers to provide their total annual expenditures on customer-acquisition activities for residential PV, segmented into three cost categories: marketing and advertising, system design, and all other customer-acquisition costs. Following the methodology explained above, these annual dollar amounts were translated into dollars per watt.

Average installer expenditures on customer-acquisition activities totaled $\$ 0.67 / \mathrm{W}$ for a typical 5 $\mathrm{kW}$ residential PV installation: \$0.11/W for system design, \$0.33/W for marketing and advertising, and $\$ 0.23 / \mathrm{W}$ for all other customer-acquisition $\operatorname{costs}^{7}$ (Table 3).

\footnotetext{
7 "All other customer acquisition costs" include sales calls, site visits, travel time to and from the site, contract negotiation with the system host/owner, and bid/pro-forma preparation - but exclude marketing/advertising and system design.
} 
Table 3. Customer-acquisition costs for residential PV installers

\begin{tabular}{|l|c|}
\hline \multicolumn{1}{|c|}{ Cost Component } & Cost $(\$ / W)$ \\
\hline System design & 0.11 \\
\hline Marketing and advertising & 0.33 \\
\hline All other customer-acquisition costs & 0.23 \\
\hline Total & $\mathbf{0 . 6 7}$ \\
\hline
\end{tabular}

Total customer-acquisition costs do not appear to exhibit strong economies of scale associated with an installer's number of installations per year. As shown in Figure 1, the majority of lowvolume installers (those with fewer than 500 total annual installations) and the two highestvolume installers (with more than 1,000 annual installations) all reported total customeracquisition costs of $\$ 0.50 / \mathrm{W}$ or less. Figure 1, however, indicates that customer-acquisition costs varied significantly among the low-volume installers surveyed, with seven reporting costs of $\$ 1.00 / \mathrm{W}$ or more and 18 reporting costs of $\$ 0.25 / \mathrm{W}$ or less.

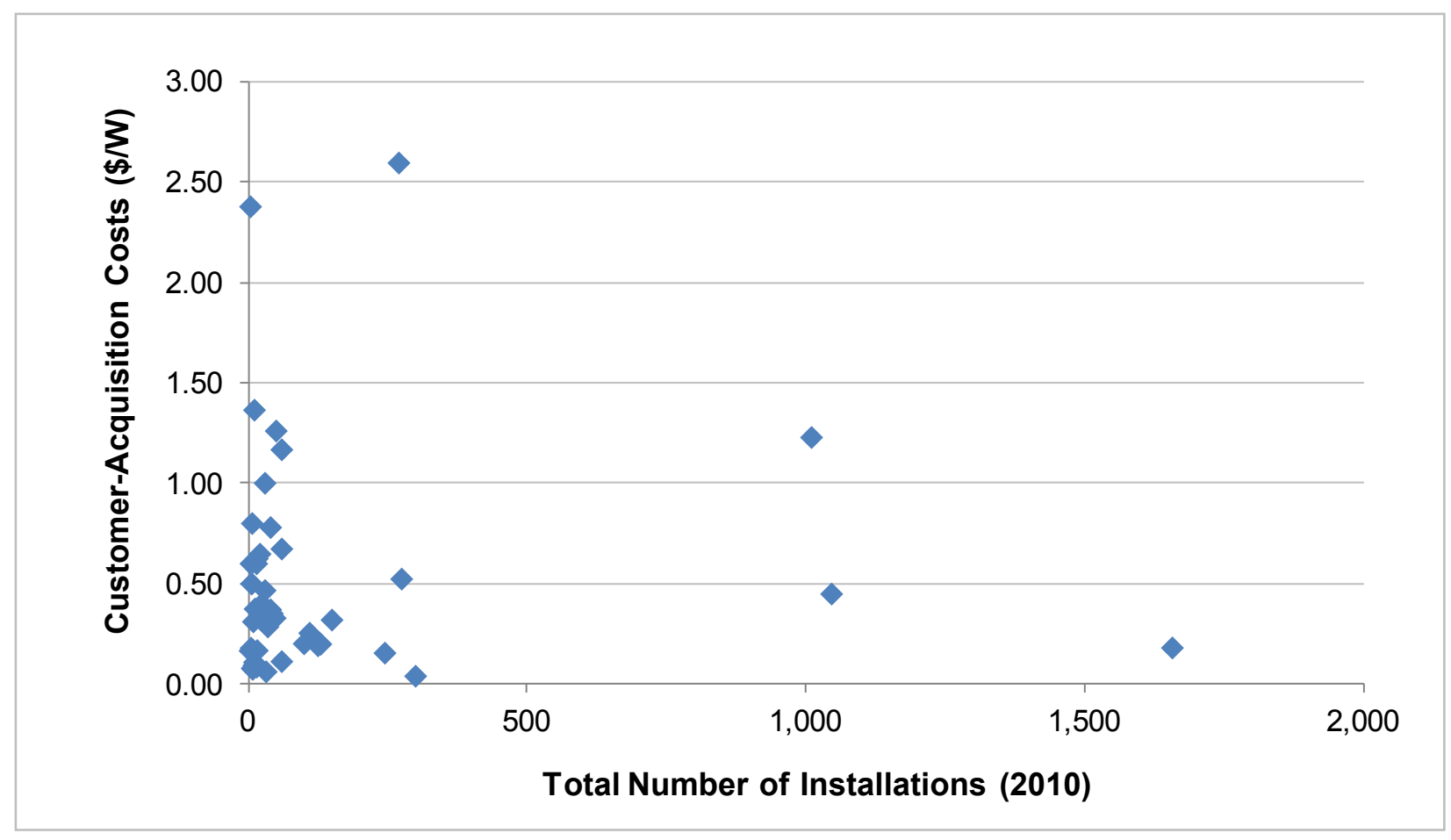

Figure 1. Reported customer-acquisition costs for each residential installer surveyed

\subsubsection{Permitting, Inspection, and Interconnection}

Regulatory requirements and permitting processes for U.S. PV installations are often burdensome and costly compared with those in leading PV nations such as Germany (Langen 2010). Installers expend significant resources on paperwork completion and compliance.

Additionally, the lack of standardization in permitting and interconnection requirements and fees across more than 18,000 authorities having jurisdiction (AHJ) and more than 5,000 utilities 
impedes installers' ability to deploy solar technology rapidly across numerous jurisdictions and utility service territories. Incentive application procedures add to these requirements and costs.

Our analysis of PII labor requirements includes the following elements:

- Permit Preparation - determination of a jurisdiction's permitting requirements, travel time to site, drawing of system plans, structural calculations, zoning application, and delays

- Permit Package Submittal - travel time to and from the permitting office and wait time at the permitting office

- Permitting Inspection - paperwork, travel time to and from the site, wait time for inspector, and physical inspection

- Interconnection Process - paperwork, travel time to and from the site, wait time for representative from utility, and physical interconnection

- Financial Incentive Application Process - determination of eligibility, paperwork, travel time to and from the site, wait time for inspector, and physical inspection

The estimated labor costs associated with completing these PII procedures totaled $\$ 0.13 / \mathrm{W}$ on average. Most installers reported total PII labor per installation within the range of 15-25 hours, or $\$ 0.08 / \mathrm{W}-\$ 0.15 / \mathrm{W}$. The two largest-volume installers (with more than 1,000 annual installations) reported approximately 20 total PII labor hours, indicating no definitive economies of scale between PII processing times and installer volume. As such, total PII costs may be more dependent on jurisdictional factors than on installer experience or annual volume. In some jurisdictions and utility service territories, cumbersome permitting and interconnection requirements deter solar development entirely. This dynamic, although not captured on a \$/W basis here, is costly in that it limits the overall growth of the residential PV market (Rocky Mountain Institute, 2012). Table 4 shows average total PII costs, including the capacity-weighted average PII labor costs, by category, with an assumed permitting fee of $\$ 430$. Figure 2 shows total PII labor hours per installation by installer volume.

Table 4. Average total residential permitting, inspection, and interconnection costs

\begin{tabular}{|l|c|}
\hline \multicolumn{1}{|c|}{ Cost Component } & Cost $(\$ / W)$ \\
\hline Permit preparation & 0.05 \\
\hline Permit submittal & 0.02 \\
\hline Inspection & 0.03 \\
\hline Interconnection & 0.01 \\
\hline Financial incentive application process & 0.02 \\
\hline Fee & .09 \\
\hline Total & $\mathbf{0 . 2 2}$ \\
\hline
\end{tabular}




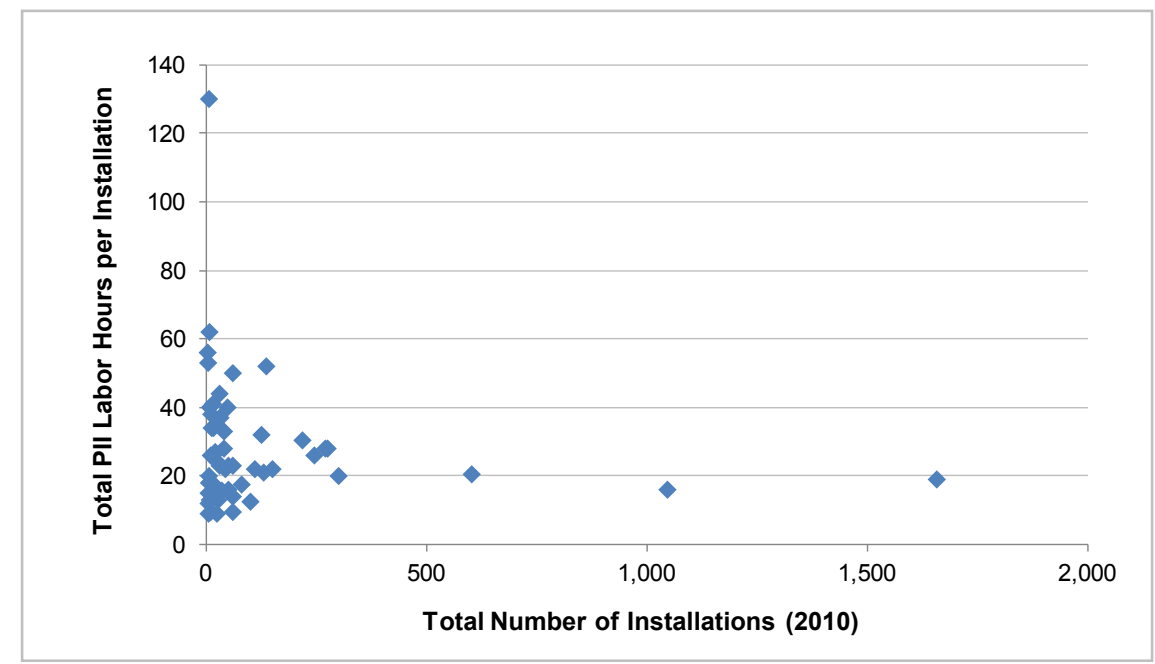

Figure 2. Total permitting, inspection, and interconnection labor-hour requirements per installation for each residential installer surveyed

Of the five PII processes examined in this analysis, installers reported the greatest labor-hour requirements for permit preparation, with $41 \%$ of installers reporting 10 or more labor hours per installation. Only $7 \%$ of installers reported 10 or more labor hours per installation for permit submittal, $2 \%$ for inspection, $8 \%$ for interconnection, and $25 \%$ for financial incentive application. Installers reported the lowest labor hour requirements per installation for interconnection, with a median of 2 labor hours per installation. Figure 3 details the labor-hour requirements for the five PII processes analyzed. Note that labor class and wage assumptions as well as labor hours affect labor costs. For example, labor class and wage assumptions make inspection-related labor more costly on an hourly basis than labor related to financial incentive application (Table 1).

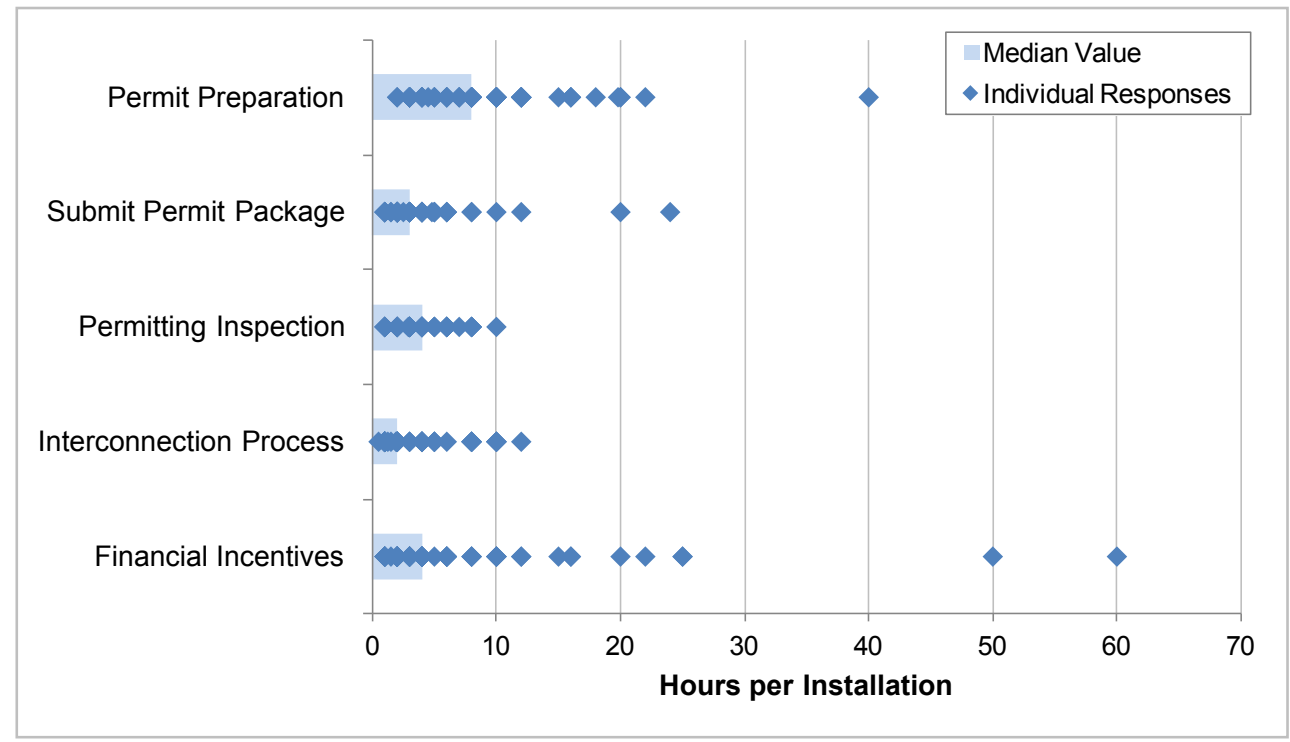

Figure 3. Hours per installation for permitting, inspection, and interconnection 
Although not surveyed for this study, permitting and interconnection fees also significantly affect total permitting costs. Total fees in the United States range from a low of $\$ 0$ per installation to an approximate high of \$2,500 per installation (Vote Solar 2011, Goodrich et al. 2012). Typical U.S. permit fees at the residential scale range from $\$ 200-\$ 450$ per installation (Vote Solar 2011, Sun Run 2011). For the purposes of this report, we assume a permitting fee of $\$ 430$ for a $5 \mathrm{~kW}$ residential system, or $\$ 0.09 / \mathrm{W}$.

\subsubsection{Installation Labor}

The survey results indicate that installation labor costs total, on average, $\$ 0.59 / \mathrm{W}: \$ 0.33 / \mathrm{W}$ for installer (roofer) labor and $\$ 0.26 / \mathrm{W}$ for electrician labor. The installer cost is higher because the higher installer labor requirements (49 hours per installation for installers vs. 26 hours per installation for electricians) more than offset the lower installer wages $(\$ 40.49 / \mathrm{h}$ for installers vs. $\$ 60.12 / \mathrm{h}$ for electricians). The estimated total average cost of $\$ 0.59 / \mathrm{W}$ closely tracks the Goodrich et al. (2012) benchmark of $\$ 0.63 / \mathrm{W}$.

While one would expect installation labor requirements to increase with installation size and exhibit some labor economies of scale, ultimately the wide spread of the data does not suggest a clear trend (Figure 4).

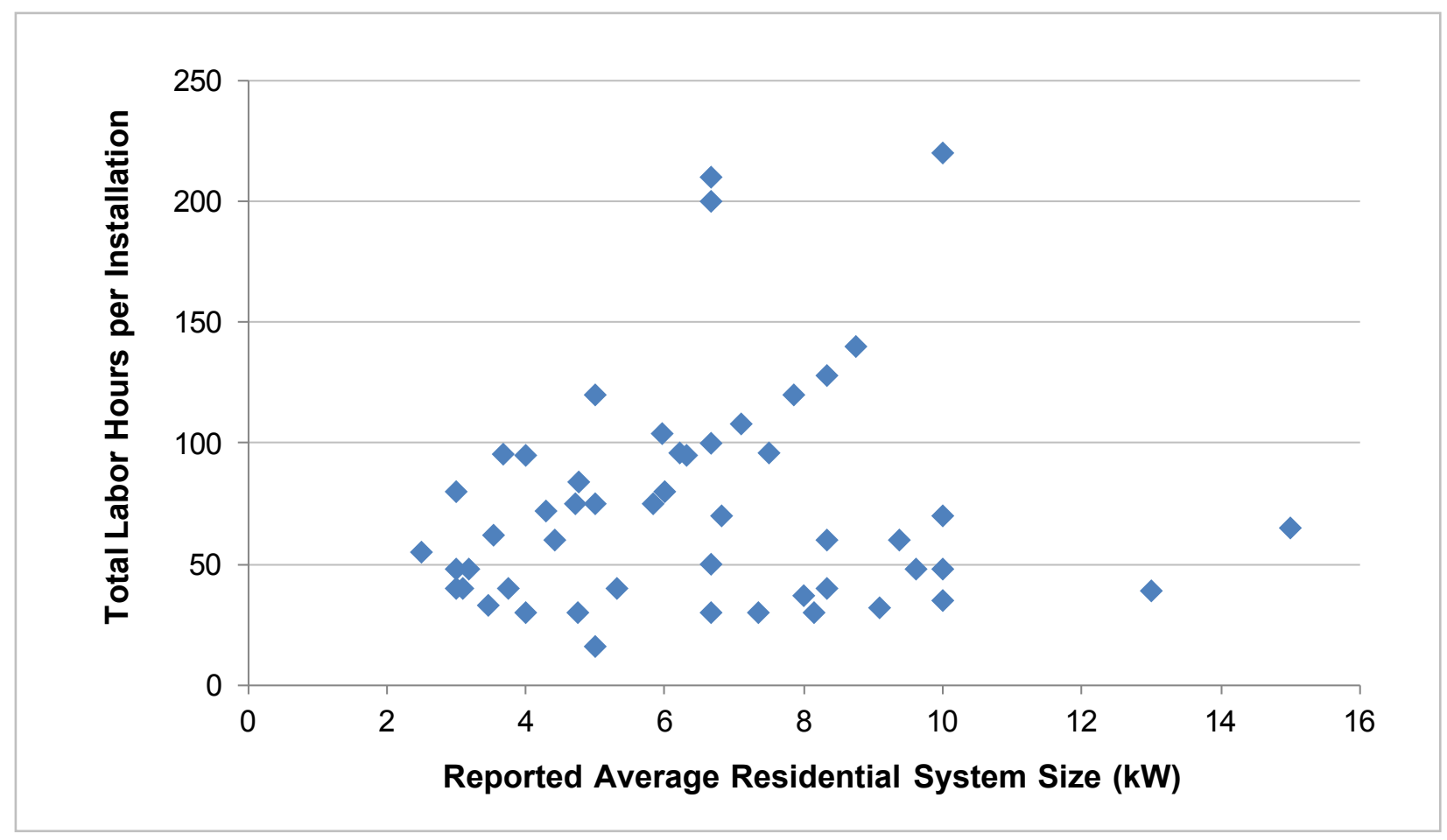

Figure 4. Total installation labor requirements by residential system size

\subsubsection{Installer Labor for Arranging Third-Party Financing}

Because the upfront capital requirements of PV installations can deter PV adoption, innovative third-party financing schemes that address these high upfront requirements, such as solar leases and power purchase agreements (PPAs), are becoming more prevalent. For example, in 2010 approximately $33 \%$ of residential systems (by capacity) installed through the California Solar 
Initiative ${ }^{8}$ used third-party financing arrangements. ${ }^{9}$ In 2011 , this percentage grew to approximately 46\%. However, in 2011 the reported installed price per watt of third-partyfinanced residential systems was, on average, $5 \%$ higher than the price of self-owned systems. Our survey sheds some light on the third-party-financing costs incurred by residential PV installers.

The survey attempted to benchmark the additional labor costs of arranging third-party financing. Installers were asked to report the average number of labor hours spent working with fund providers of third-party leases and PPAs. The installers reported spending an average of 2.4 labor hours working with third-party fund providers, translating into $\$ 0.02 / \mathrm{W}$ for a $5 \mathrm{~kW}$ system. Of the 66 respondents, 18 assisted with third-party leases, and 7 assisted with third-party PPAs. Overall, $46 \%$ of installations were financed through third-party mechanisms. PV systems completed by smaller-volume installers were more likely to be financed through direct cash purchase (for which we assumed zero financing-related installer labor) compared with systems completed by large-volume installers (Figure 5). In addition, smaller installers tended to spend more hours per installation working with third-party fund providers. Installers who built fewer than 30 projects per year spent 4.8 hours on average, vs. 2.6 hours for installers who built 301,000 projects per year and 2.4 hours for those who built more than 1,000 projects per year.

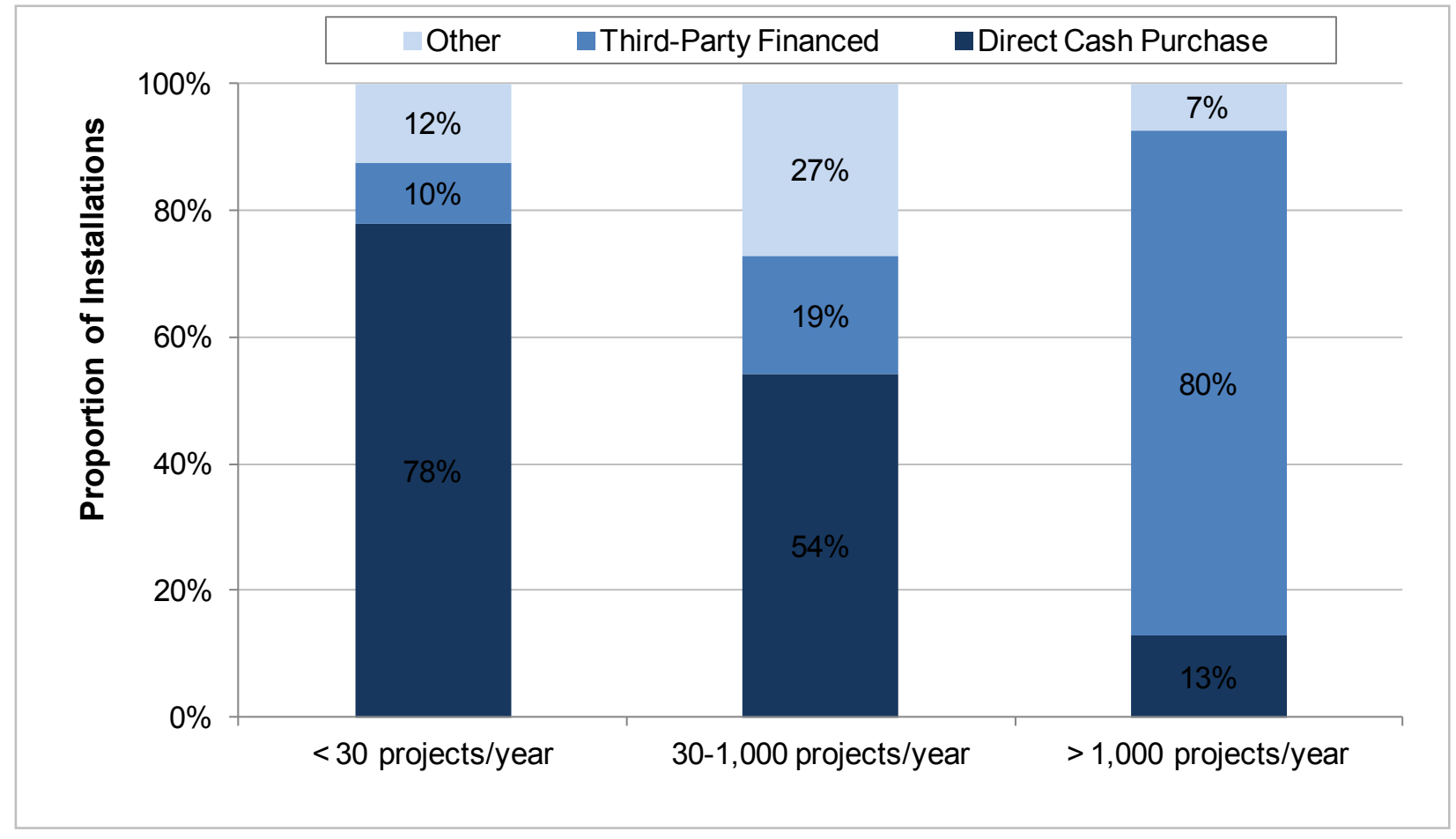

Figure 5. Residential PV system financing structure, by installer volume

\footnotetext{
${ }^{8}$ In 2011, the California Solar Initiative constituted $93 \%$ of all California, and $36 \%$ of all U.S., residential capacity installed.

${ }_{9}^{9}$ Data from the California Solar Initiative Database (www.californiasolarstatistics.ca.gov/current data files/), accessed June 20, 2012.
} 
Installer labor for arranging third-party financing likely constitutes a small portion of the total costs related to third-party financing of residential PV systems. Our survey included questions designed to elicit a more comprehensive picture of system financing costs from the installer perspective, but the responses were insufficient for drawing meaningful conclusions. This is an important area of research being undertaken by NREL and Rocky Mountain Institute researchers. In addition to costs attributed to extra services included with third-party-financed systems - such as system monitoring and electricity-production guarantees - third-party financing mechanisms incur costs related to the complex relationship among their financial structures, investors, and government or utility incentives. Specific potential costs include, but are not limited to, additional installer labor and overhead associated with internally vetting the creditworthiness of a system host; legal, accounting, and independent engineering fees associated with reviewing financing contracts; fees associated with setting up tax equity and debt facilities, including billing and collection costs, audits, and working capital reserve; interest paid during construction; and the cost of construction insurance. Of course, taking on the costs associated with third-party financing only makes sense if the added benefits (e.g., from government incentives, increased access to capital markets, and overcoming first-cost barriers) outweigh the added costs. Based on the observed increase in third-party financing during the past few years, this seems to be the case. As part of our ongoing and future research, we are working to enable a better understanding of residential PV financing and its impacts on PV system prices and to develop benchmarks for tracking reductions in financing costs over time.

\section{Commercial PV System Data Collection and Results}

\subsection{Sample Market Representation and Characterization}

Seventeen commercial PV installers responded to the survey. These installers reported completing 247 commercial PV systems in 2010, totaling $85 \mathrm{MW}$ and representing roughly $5 \%$ of all commercial PV systems and $23 \%$ of all commercial PV capacity installed in the United States in 2010. As with the residential survey, we cleaned the data for outliers, and 13-15 valid responses remained per question (representing approximately $4 \%$ of all commercial PV systems installed in the United States in 2010). Given the small sample size for the commercial survey, caution should be exercised when generalizing from the findings.

The sample primarily consists of relatively small-volume commercial installers (Figure 6); only two respondents completed more than 20 commercial systems in 2010 . The large majority (12 out of 17) of respondents completed fewer than 10 systems in 2010, suggesting that some have a broader scope of business (e.g., electrical contractors or engineering firms) and do not exclusively focus on PV installations or may serve both residential and commercial PV markets.

Commercial PV systems vary considerably in size, and the respondents include installers specializing in both small and large commercial systems (Figure 7). Of the 17 respondents, 6 installed systems averaging less than $100 \mathrm{~kW}$ in 2010 , while 5 reported an average system size larger than $500 \mathrm{~kW}$ (with the remainder falling in between those average system sizes). 


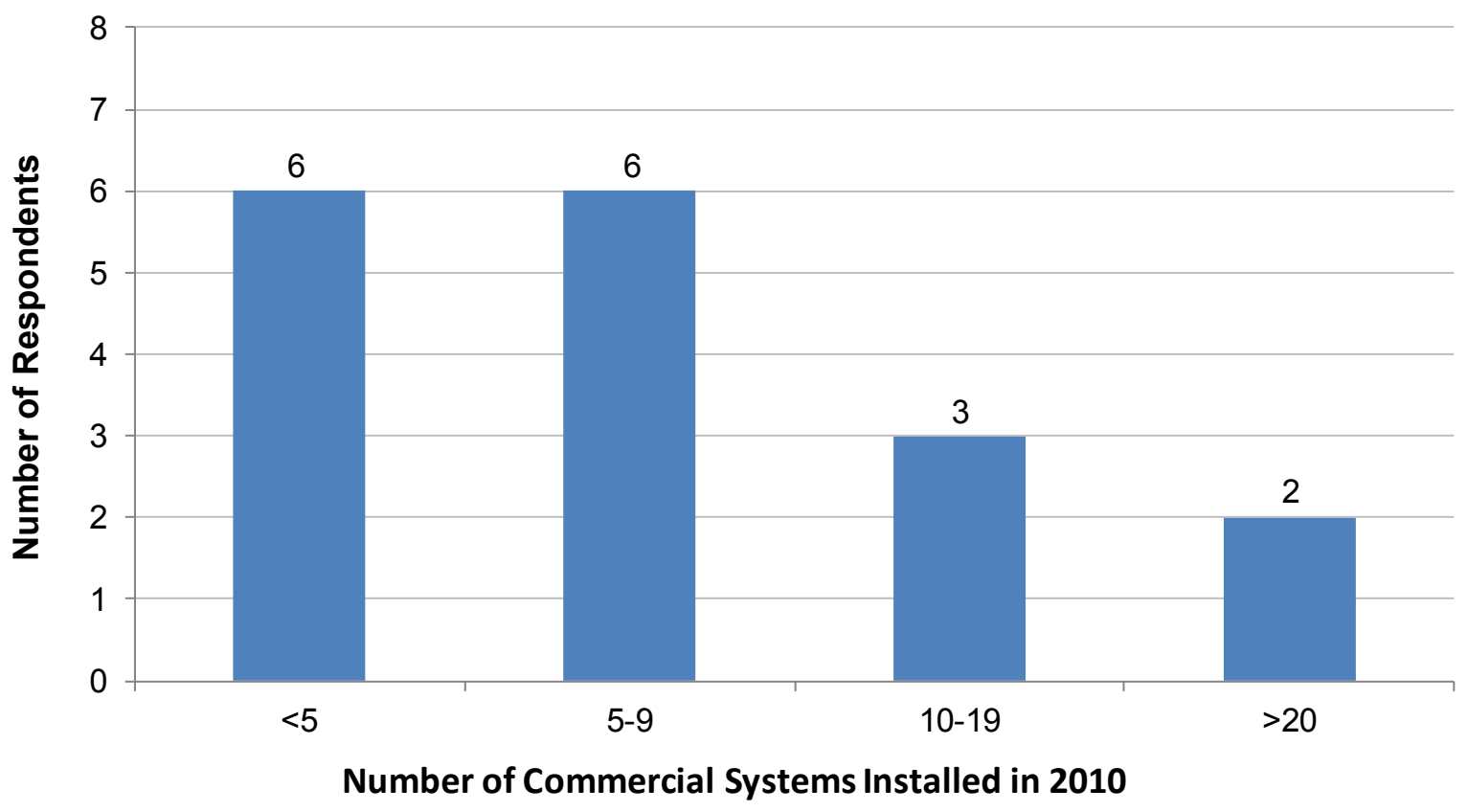

Figure 6. Number of commercial PV systems installed in 2010 by survey respondents

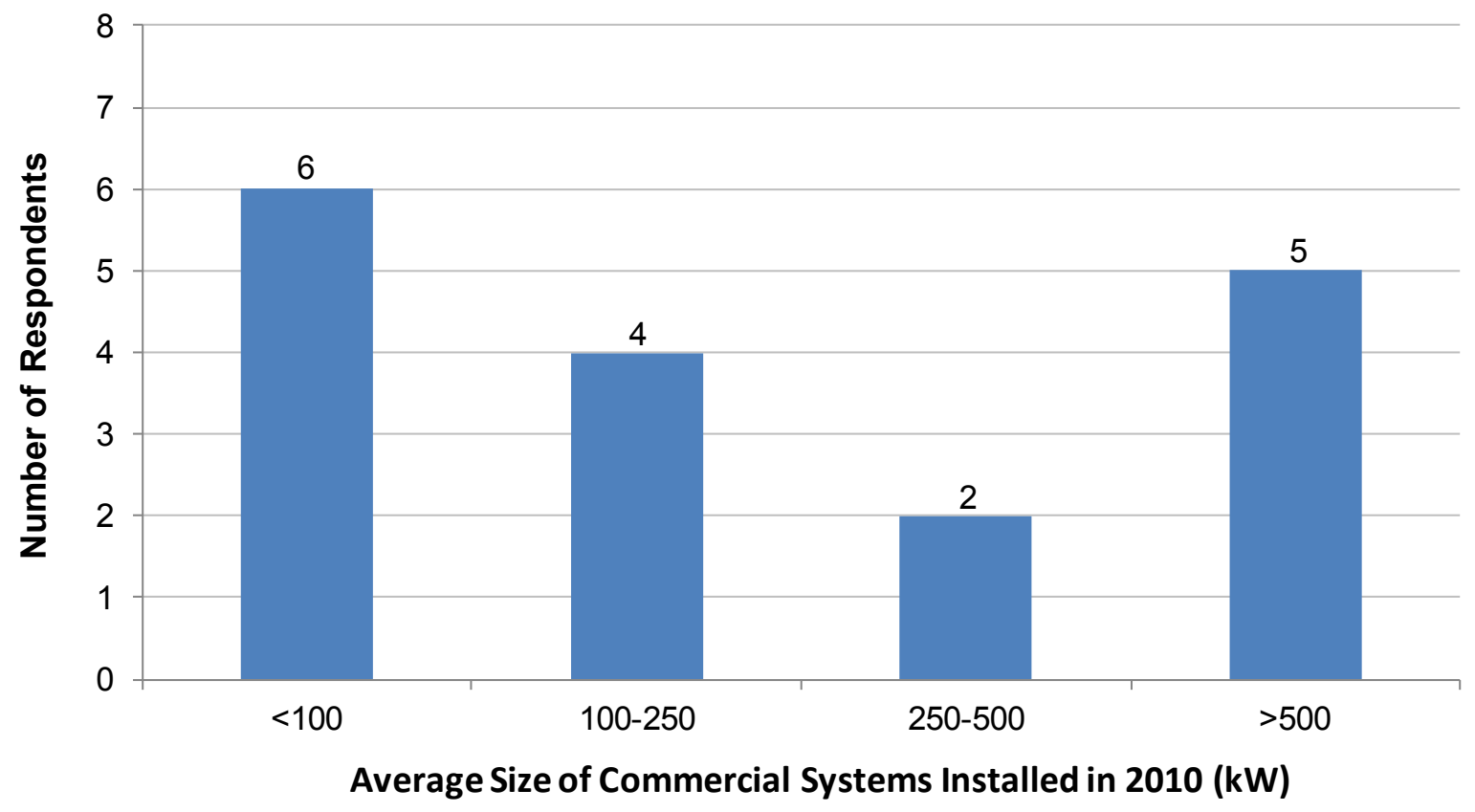

Figure 7. Average size of commercial PV systems installed in 2010 


\subsection{Commercial Results}

For most soft-cost categories examined, survey questions were in terms of average labor hours per system installed. For each installer surveyed, these responses were translated into units of dollars per watt based on the average system size of that particular installer and assumed labor rates (Table 1). For customer-acquisition costs, survey questions were, instead, in terms of annual dollar expenditures. These survey responses were translated into dollars per watt for each installer based on the total capacity of commercial systems installed in 2010.

Survey responses for commercial installers are summarized here in terms of the median value across respondents. Given the relatively small sample of commercial installers, this metric was deemed more meaningful than a simple or capacity-weighted average (as was used for residential PV). To illustrate how soft costs for commercial PV may differ depending on the size of the system installed, we separately report median values for installers with an average system size smaller than $250 \mathrm{~kW}$ and for those with an average system size larger than $250 \mathrm{~kW}$.

\subsubsection{Customer Acquisition}

The survey asked installers to provide their total annual expenditures on customer-acquisition activities for commercial PV, segmented into three cost categories: advertising and marketing, system design, and all other customer-acquisition costs. Following the methodology explained above, these annual dollar amounts were translated into dollars per watt.

Across all commercial PV installers surveyed, median customer-acquisition costs totaled $\$ 0.10 / \mathrm{W}$ (Figure 8), with almost all respondents reporting total customer-acquisition costs of less than $\$ 0.20 / \mathrm{W}$ on average (Figure 9). System design constitutes the largest component of customer-acquisition costs $(\$ 0.07 / \mathrm{W})$, advertising and marketing constitute $\$ 0.01 / \mathrm{W}$, and other costs make up the remainder.

Customer-acquisition costs appear to exhibit strong economies of scale, with median costs of $\$ 0.19 / \mathrm{W}$ for installers with an average system size smaller than $250 \mathrm{~kW}$ versus $\$ 0.03 / \mathrm{W}$ for installers with an average system size larger than $250 \mathrm{~kW}$. Figure 9, however, indicates that customer-acquisition costs vary significantly among the small commercial installers surveyed, with some reporting costs similar to those of large commercial installers and others reporting significantly higher costs.

Also of note is the $\$ 0.57 / \mathrm{W}$ gap between the customer-acquisition costs reported by commercial installers and those reported by residential installers $(\$ 0.67 / \mathrm{W})$. A substantial share of that gap is associated with the much lower marketing and advertising costs reported by commercial installers (roughly $\$ 0.01 / \mathrm{W})$ compared with those reported by residential installers $(\$ 0.33 / \mathrm{W})$. 


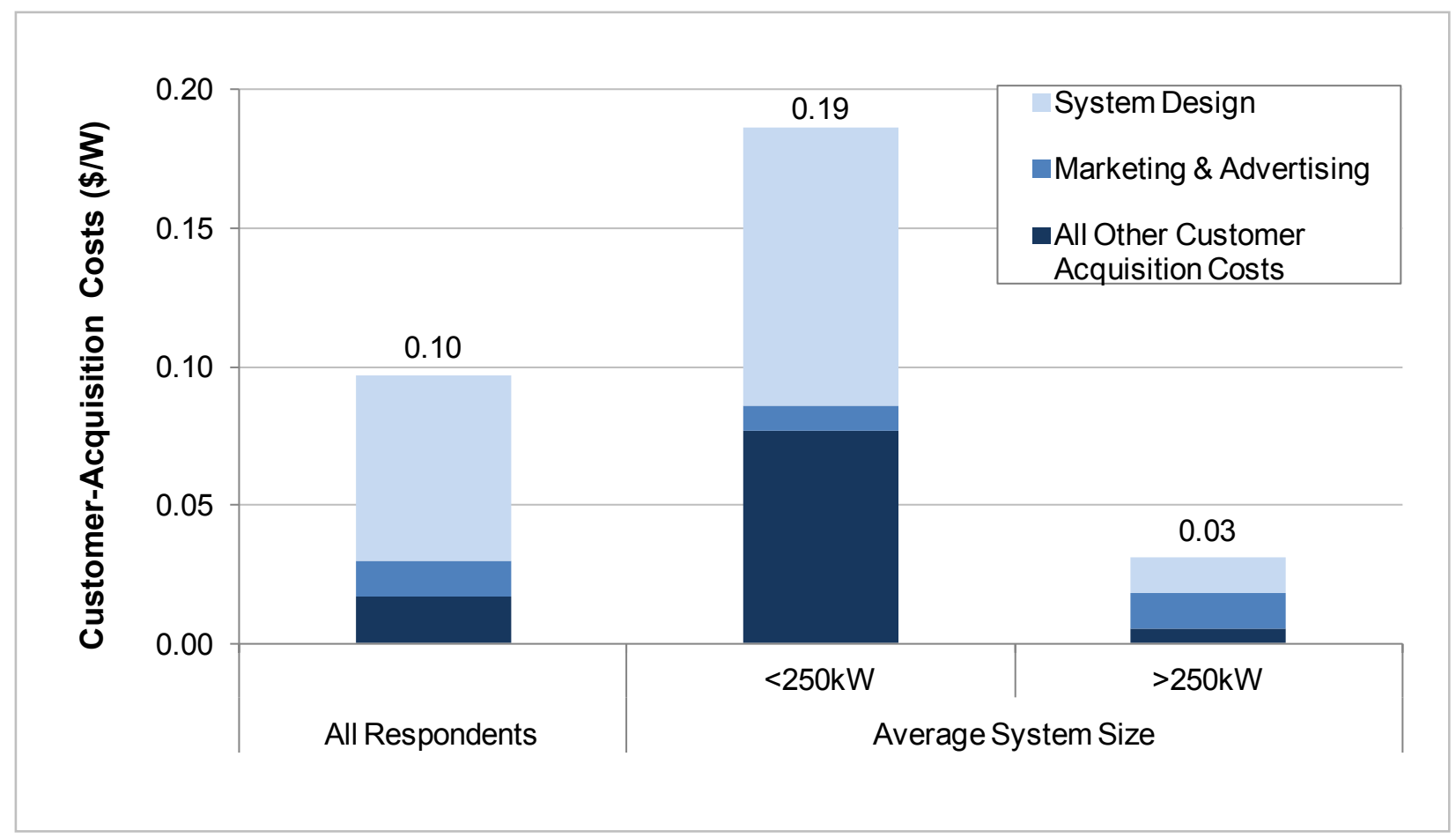

Figure 8. Median customer-acquisition costs for commercial PV installers

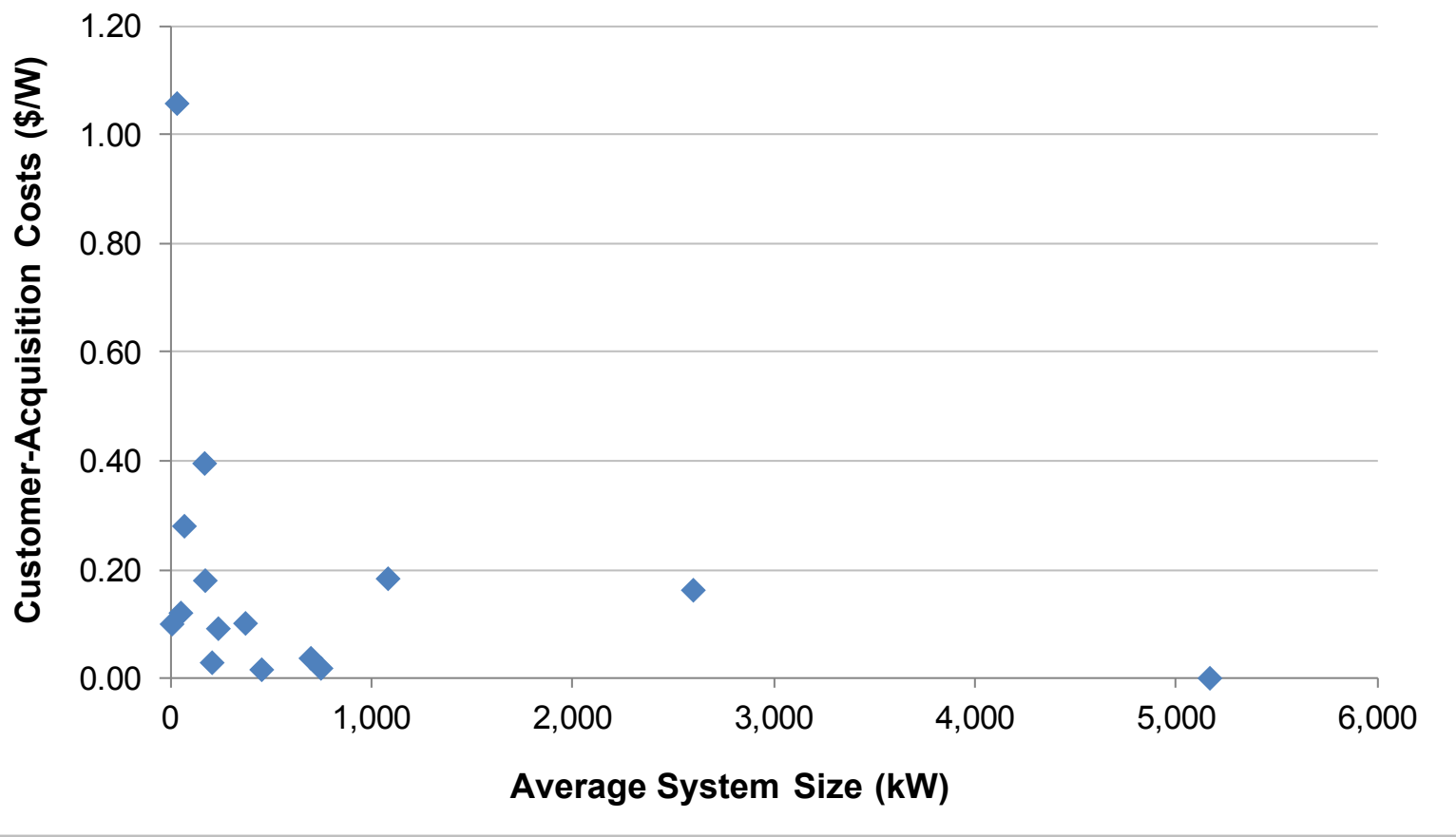

Figure 9. Reported customer-acquisition costs for each commercial installer surveyed

\subsubsection{Permitting, Inspection, and Interconnection}

The survey asked commercial installers for the average number of labor hours per installation associated with PII processes, segmented into the five activities described in Section 4.2.2. As 
shown in Figure 10, the reported average number of labor hours for all five PII activities varied widely across installers, ranging from roughly 20 hours to almost 500 hours per system, with a median response of 67 hours. PII labor requirements were typically higher for larger systems; the median for installers with average system sizes larger than $250 \mathrm{~kW}$ was 72 hours per system, compared with 41 hours per system for installers with average system sizes smaller than $250 \mathrm{~kW}$. This difference is to be expected given the generally greater complexity of PII processes for larger systems.

Based on assumed labor rates and each installer's average system size, PII labor costs amount to less than $\$ 0.01 / \mathrm{W}$ across the full set of commercial installers surveyed, with permit preparation constituting the largest underlying labor cost (Figure 11). Although labor requirements are greater for larger commercial PV systems in terms of labor hours per installation, the associated costs on a per-watt basis are lower because the absolute dollar costs are spread across a larger number of installed watts.

As with the residential survey results, the PII labor costs reported here for commercial PV do not include the cost of permitting or interconnection fees, which may significantly exceed the direct PII labor costs. For the purposes of this report, we assume a $\$ 25,000$ permit fee (typical for commercial PV systems), which equates to an additional $\$ 0.35 / \mathrm{W}$, in the median case, among survey respondents with average system sizes smaller than $250 \mathrm{~kW}$ (assuming a system size of $72 \mathrm{~kW}$, the average size among this group) and $\$ 0.03 / \mathrm{W}$ among respondents with average system sizes larger than $250 \mathrm{~kW}$ (assuming a system size of $750 \mathrm{~kW}$, the average size among this group).

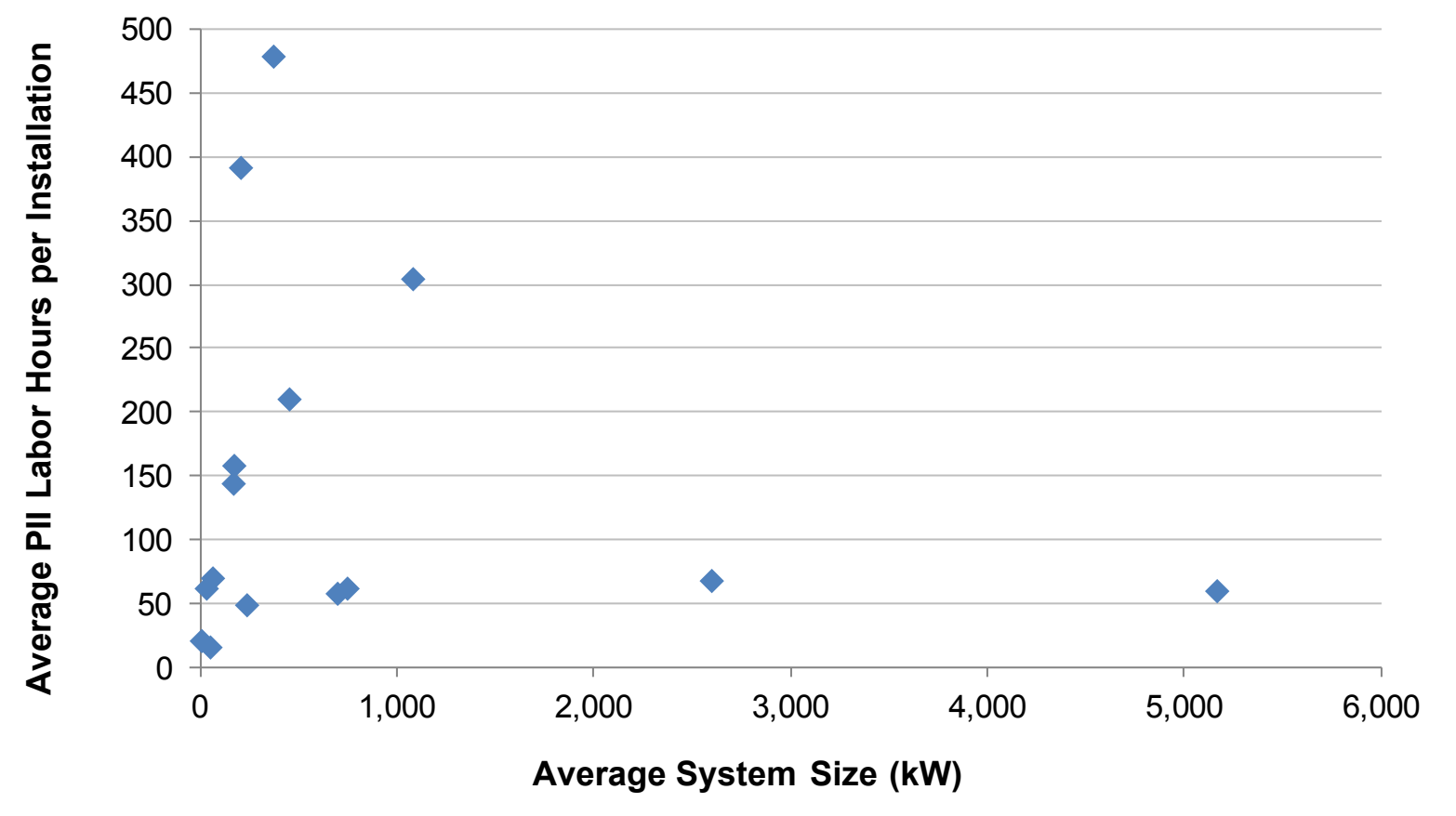

Figure 10. Hours per commercial installation for permitting, inspection, and interconnection, processes 


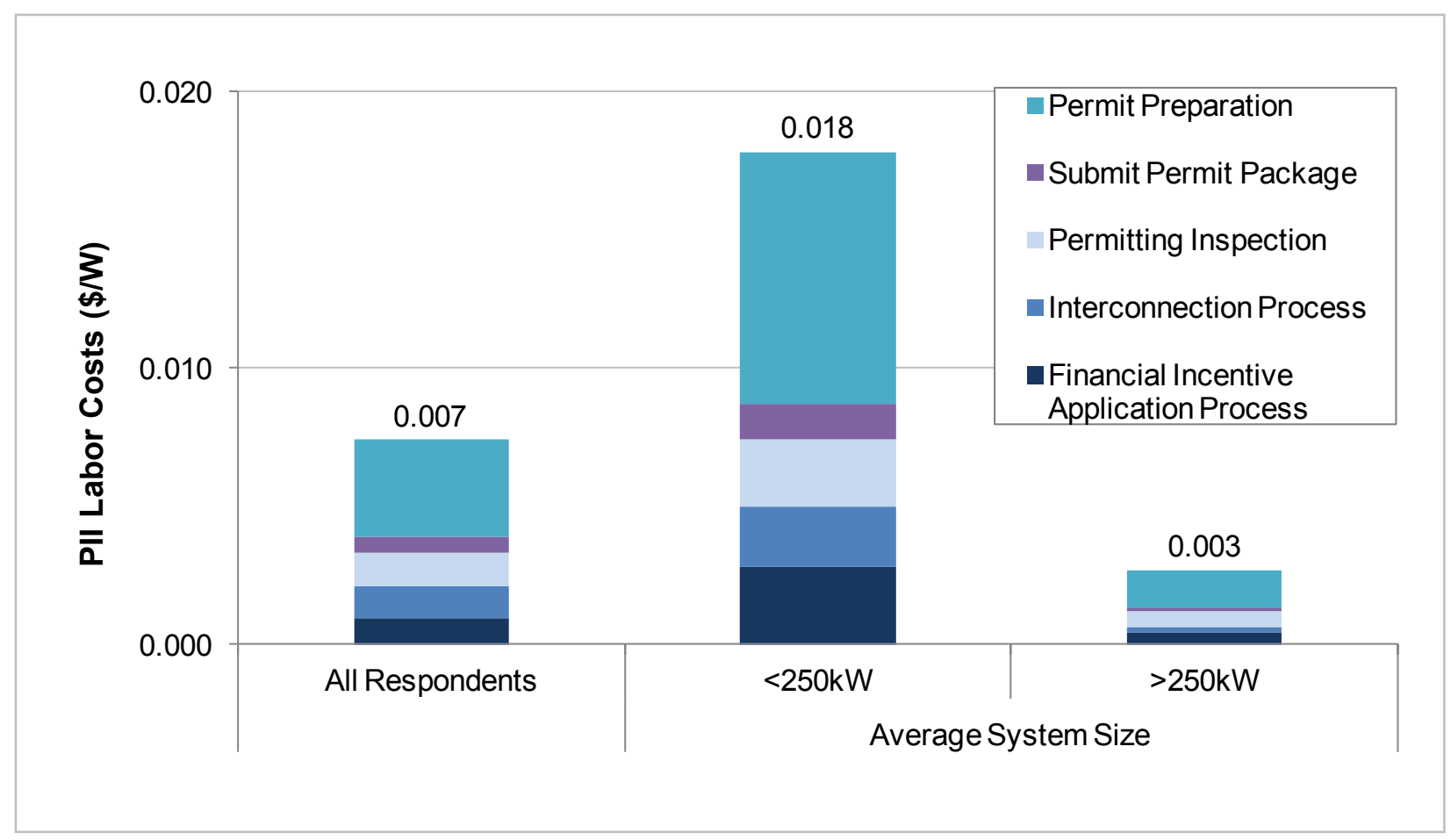

Figure 11. Median permitting, inspection, and interconnection labor costs for commercial PV installers (excludes fees)

\subsubsection{Installation Labor}

The reported average number of hours required to install a commercial PV system varies substantially across the installers surveyed. Among all 13 installers who provided valid responses to the relevant survey questions, the median installation labor requirement was 4 hours $/ \mathrm{kW}$, with roughly a $40 \% / 60 \%$ split between electrician and installer (roofer) labor. Larger systems appear to benefit from significant scale economies; installers with average system sizes larger than $250 \mathrm{~kW}$ reported a median of 3 hours $/ \mathrm{kW}$ compared with 8 hours $/ \mathrm{kW}$ for installers with average system sizes smaller than $250 \mathrm{~kW}$. These scale economies appear to be most closely associated with installer (roofer) labor, whereas electrician labor appears to increase more or less proportionately with system size.

Based on assumed labor rates and each installer's average system size, installation labor costs amount to roughly $\$ 0.21 / \mathrm{W}$ across all commercial installers surveyed (Figure 12). Given the lower labor productivity rates mentioned above, installation labor costs are appreciably higher for small commercial systems. Respondents with average system sizes smaller than $250 \mathrm{~kW}$ have a median value of $\$ 0.42 / \mathrm{W}$ compared with $\$ 0.18 / \mathrm{W}$ for respondents with average system sizes larger than $250 \mathrm{~kW}$. 


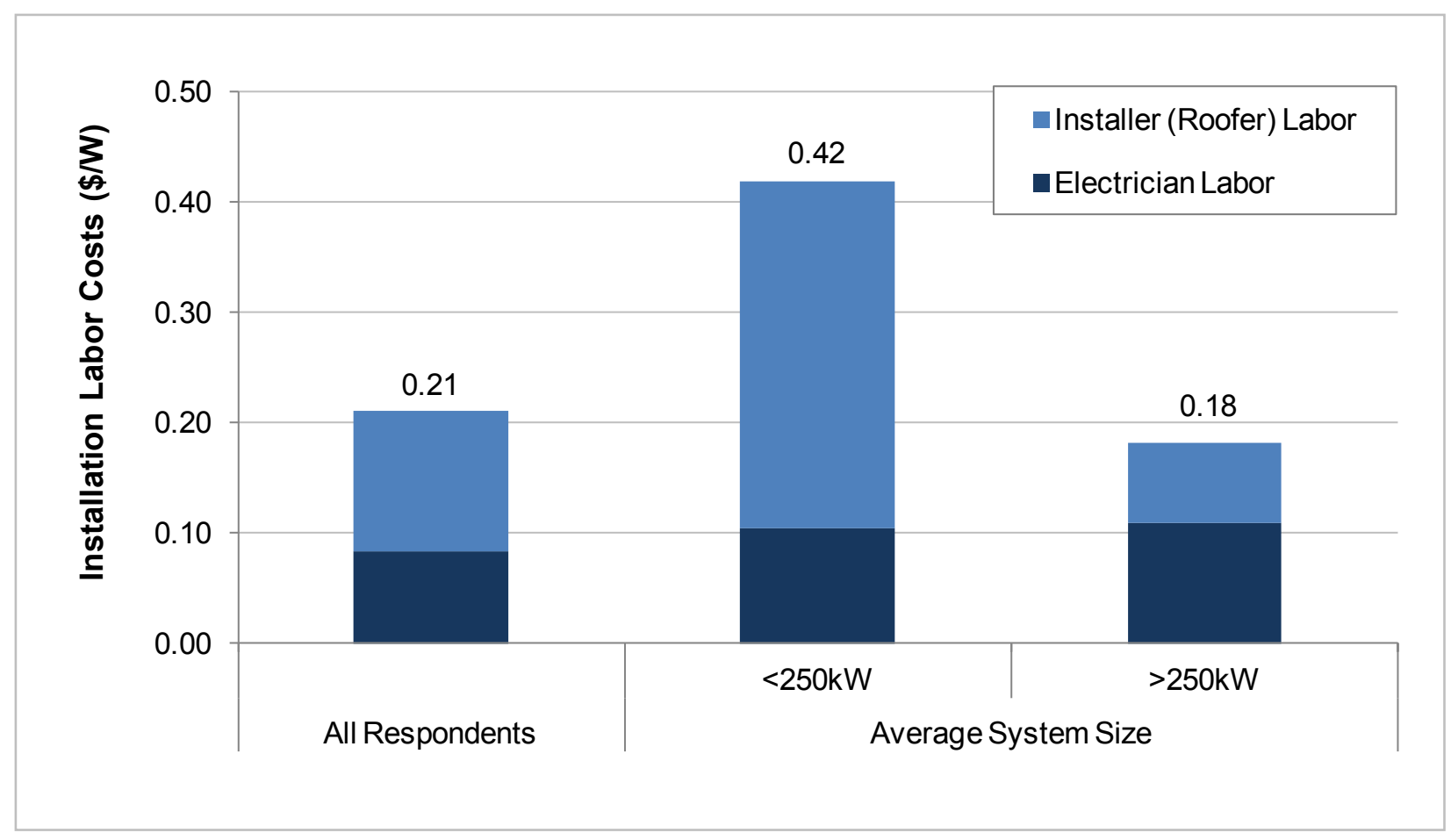

Figure 12. Median installation labor costs for commercial PV installers

\subsubsection{Installer Labor for Arranging Third-Party Financing}

Among the commercial installers surveyed, roughly $35 \%$ of all systems completed in 2010 involved some form of third-party financing (either leases or PPAs). The remaining installations were either direct cash-sale transactions or involved installer-assisted bank or government loans.

Installers bear additional labor costs when helping their customers obtain third-party financing, for example via labor costs for working with fund providers or other contractual counterparties. The median reported labor costs associated with third-party financing totaled 60 hours per system. Based on assumed labor rates and each installer's average system size, these labor requirements equate to roughly $\$ 0.02 / \mathrm{W}$ for respondents with average system sizes smaller than $250 \mathrm{~kW}$ and less than $\$ 0.01 / \mathrm{W}$ for respondents with average system sizes larger than $250 \mathrm{~kW}$.

Installers confront similar financing challenges for commercial systems as for residential systems (see Section 4.2.4), although commercial PV typically incurs greater absolute transaction costs owing to the larger system size and higher installed cost. While commercial PV systems can be similar in size to residential systems, which rarely cost more than $\$ 35,000$, they can also be very large ground-mounted or rooftop systems costing several million dollars to install. Further, many businesses are averse to allocating the time or money needed to own and maintain a PV system. For these reasons, it is important to understand the full financing and contracting costs of building a commercial PV system. As with residential PV, installer labor costs associated with arranging third-party financing for commercial PV are one of many potential financing costs. As part of our ongoing and future research, we are working to enable a better understanding of commercial PV financing and its impacts on PV system prices and to develop benchmarks for tracking reductions in financing costs. 


\section{Study Limitations}

This report summarizes the soft costs that PV installers incurred when completing residential and commercial projects in 2010. However, the analysis has limitations. First, after eliminating the top and bottom $5 \%$ of responses, the sample size of installers across the United States is small (up to 60 installer responses per cost category for residential and up to 15 installer responses per cost category for commercial ${ }^{10}$ ), potentially magnifying the effect of response error. Second, when assessing bottom-up cost structures, the inability to identify whether some questions may be inapplicable or only marginally applicable to respondents that serve primarily as subcontractors to engineering procurement and construction firms may result in an underestimation of costs. Third, while this soft-cost data collection is the most granular to date, further data collection is necessary to capture certain costs not explicitly addressed by the survey design. For instance, while the analysis benchmarks the installer labor costs of arranging thirdparty ownership and the financial incentive application process, additional financing-related costs must be considered, such as legal fees, interest during construction, and working capital. Finally, the dataset could be enhanced with increased geographic variability. The sample representation is heavily weighted toward installers based in California, with the exception of a few large-scale installers from the east coast. This lack of geographic representation could misrepresent costs on a national basis, given the differences in market maturity across states.

\section{Summary of Survey Results}

The results of the residential installer survey suggest that the surveyed soft costs constitute a significant portion of total residential PV soft costs (Figure 13); including assumed permitting fees, the surveyed costs total $\$ 1.50 / \mathrm{W}$, equivalent to $45 \%$ of total system soft costs $(\$ 3.32 / \mathrm{W})$ and $23 \%$ of total system price in $2010(\$ 6.60 / \mathrm{W}) .{ }^{11}$ Based on a 2010 installed PV system price of $\$ 6.60 / \mathrm{W}$, the difference in total soft costs and soft costs captured by the survey totals $\$ 1.82 / \mathrm{W}$. This residual cost of $\$ 1.82 / \mathrm{W}$ is the subject of future analysis aimed at refining the granularity of PV system price benchmarks. Customer-acquisition $(\$ 0.67 / \mathrm{W})$ and installation-labor costs $(\$ 0.59 / \mathrm{W})$ are the largest of the soft costs benchmarked in this analysis, suggesting considerable cost efficiency gains can be made in these areas. However, streamlining PII requirements (\$0.13/W for select PII costs in this analysis) is also an important cost-reduction opportunity. PII costs account for an estimated $25 \%-35 \%$ of the price difference between U.S. and German residential PV prices. ${ }^{12}$ Finally, while the benchmarked installer labor costs for arranging thirdparty financing are negligible $(\$ 0.02 / \mathrm{W})$, additional data on financing costs are needed to depict the cost of financing and contracting PV systems more completely and accurately.

As shown in Figure 13, the surveyed soft costs also constitute a significant portion of total commercial PV soft costs, although their impact depends significantly on system size. For small

\footnotetext{
${ }^{10}$ Sample size and representation vary by cost category.

${ }^{11}$ The total average system price for residential PV is based on the average installed prices cited by Barbose et al. (2011) for residential PV systems of comparable size installed in 2010. The value for total soft costs is then calculated as the difference between total average installed price and the sum of all hardware-related costs for 2010 residential PV systems (Goodrich 2012). The sum of hardware-related costs for 2010 is based on the fourth quarter of 2009, which differs from Goodrich et al. (2012) hardware cost benchmarks based on the fourth quarter of 2010.

${ }^{12}$ The $25 \%-35 \%$ estimate is based on a 2010 total difference in price of $\$ 1.98 / \mathrm{W}$ between the United States and Germany, which includes $\$ 0.18 / \mathrm{W}$ for permitting and commissioning and $\$ 0.30 / \mathrm{W}$ for additional overhead in the United States in 2010 (Goodrich 2012).
} 
commercial systems (smaller than $250 \mathrm{~kW}$ ), the surveyed costs (including assumed permitting fees of $\$ 0.35 / \mathrm{W})$ total $\$ 0.99 / \mathrm{W}$, equivalent to roughly $37 \%$ of all soft costs $(\$ 2.64 / \mathrm{W})$ and roughly $17 \%$ of the total average system price in 2010 for commercial systems in that size range $(\$ 5.96 / \mathrm{W})$. In contrast, surveyed soft costs for large systems (larger than $250 \mathrm{~kW}$ ) are just $\$ 0.25 / \mathrm{W}$ (including $\$ 0.03 / \mathrm{W}$ for assumed permitting fees), or $12 \%$ of all soft costs $(\$ 2.16 / \mathrm{W})$ and $5 \%$ of the total average system price in $2010(\$ 5.33 / \mathrm{W}) .{ }^{13}$

Of the various commercial PV labor-related soft costs, installation labor is by far the most significant: \$0.42/W for small systems and \$0.18/W for large systems. This suggests that efforts to reduce commercial PV system costs ought to focus on this category. Customer acquisition adds $\$ 0.19 / \mathrm{W}$ to the cost of small commercial systems but only $\$ 0.03 / \mathrm{W}$ for large systems because large systems benefit from economies of scale and the ability to spread those (relatively) fixed costs over a larger number of installed watts. Labor costs associated with PII and arranging third-party financing are generally negligible $(\$ 0.02 / \mathrm{W}$ or less) for the surveyed commercial PV installers. Table 5 summarizes the soft costs considered in this analysis for residential and commercial systems.

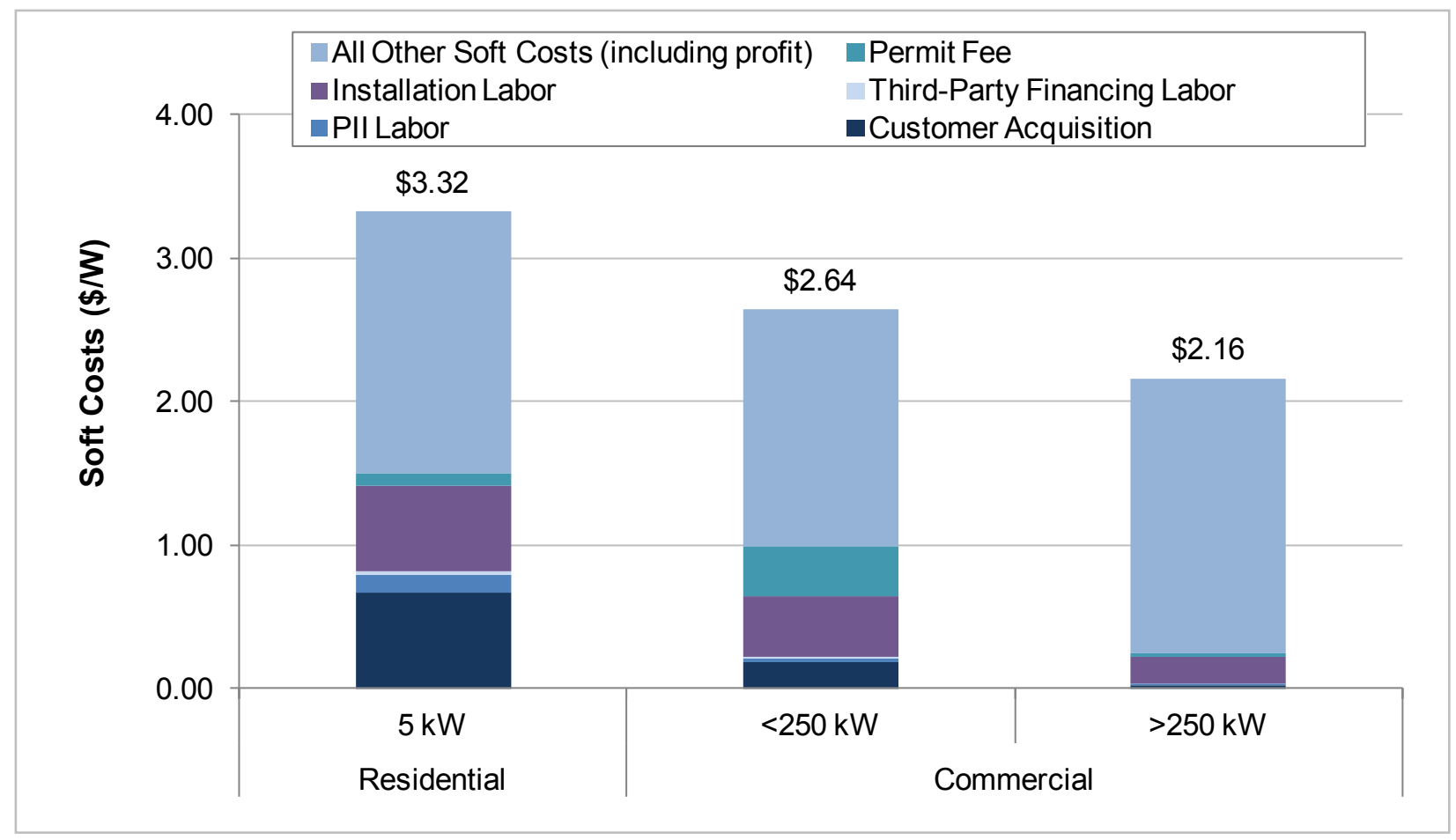

Figure 13. Total soft costs, by system size

The plotted values are derived from our survey (installation labor, installer third-party financing labor, PII labor, and customer acquisition), Barbose et al. (2011) and Goodrich et al. (2012) (all other soft costs), and assumptions (permit fee). All other soft costs include profit, overhead, sales tax, non-labor financing and contracting costs, and additional costs due to market friction and inefficiencies.

\footnotetext{
${ }^{13}$ The total average system price for commercial PV is based on the average installed prices cited by Barbose et al. (2011) for commercial PV systems of comparable size installed in 2010. The value for total soft costs is then calculated as the difference between total average installed price and the sum of all hardware-related costs for 2010 commercial PV systems (Goodrich 2012). The sum of hardware-related costs for 2010 is based on the fourth quarter of 2009, which differs from Goodrich et al. (2012) hardware cost benchmarks based on the fourth quarter of 2010.
} 
Table 5. Summary of selected residential and commercial PV system soft costs (2010)

\begin{tabular}{|c|c|c|c|c|c|c|}
\hline \multirow{2}{*}{$\begin{array}{l}\text { Soft Cost } \\
\text { Category }\end{array}$} & \multicolumn{2}{|c|}{ Residential Systems } & \multicolumn{2}{|c|}{$\begin{array}{l}\text { Small Commercial } \\
\text { Systems }(<250 \mathrm{~kW})\end{array}$} & \multicolumn{2}{|c|}{$\begin{array}{l}\text { Large Commercial } \\
\text { Systems (> } 250 \text { kW) }\end{array}$} \\
\hline & $\begin{array}{l}\text { Cost } \\
(\$ / W)\end{array}$ & $\begin{array}{l}\text { Proportion } \\
\text { of System } \\
\text { Price }\end{array}$ & $\begin{array}{l}\text { Cost } \\
(\$ / W)\end{array}$ & $\begin{array}{l}\text { Proportion } \\
\text { of System } \\
\text { Price }\end{array}$ & $\begin{array}{l}\text { Cost } \\
(\$ / W)\end{array}$ & $\begin{array}{l}\text { Proportion } \\
\text { of System } \\
\text { Price }\end{array}$ \\
\hline $\begin{array}{l}\text { Customer } \\
\text { acquisition }\end{array}$ & 0.67 & $10 \%$ & 0.19 & $3 \%$ & 0.03 & $1 \%$ \\
\hline $\begin{array}{l}\text { Installation } \\
\text { labor }\end{array}$ & 0.59 & $9 \%$ & 0.42 & $7 \%$ & 0.18 & $3 \%$ \\
\hline $\begin{array}{l}\text { Permitting, } \\
\text { inspection, and } \\
\text { interconnection }\end{array}$ & 0.13 & $2 \%$ & 0.02 & $0.3 \%$ & 0.003 & $0.0 \%$ \\
\hline $\begin{array}{l}\text { Labor for } \\
\text { arranging third- } \\
\text { party financing }\end{array}$ & 0.02 & $0.3 \%$ & 0.02 & $0.3 \%$ & 0.01 & $0.2 \%$ \\
\hline $\begin{array}{l}\text { Assumed } \\
\text { permitting fees }\end{array}$ & 0.09 & $1 \%$ & 0.35 & $6 \%$ & 0.03 & $1 \%$ \\
\hline $\begin{array}{l}\text { All surveyed } \\
\text { soft costs }\end{array}$ & 1.50 & $23 \%$ & 0.99 & $17 \%$ & 0.25 & $5 \%$ \\
\hline
\end{tabular}

The first four soft-cost categories reflect costs collected directly from our installer survey. Permitting fees are assumed. For calculating the proportions of PV system prices, 2010 system prices are $\$ 6.60 / \mathrm{W}$ for residential, $\$ 5.96 / \mathrm{W}$ for small commercial, and $\$ 5.33 / \mathrm{W}$ for large commercial. Individual values may not add up to totals owing to rounding.

\section{Conclusions and Future Work}

As PV system prices continue to decline owing to module and hardware cost reductions, accurately quantifying soft costs is increasingly important for explaining PV system price dynamics across various U.S. and international markets. This report presents results from a bottom-up, survey-data-driven analysis of soft costs in the DOE priority areas of customer acquisition, financing, PII, and installation. This work establishes benchmark soft costs for residential and commercial PV with the objectives of tracking costs over time, identifying opportunities for cost reductions, and informing the development of policies and practices aimed at reducing cost inefficiencies.

The soft costs collected and analyzed in this report constitute a significant portion of total installed PV system prices. As Table 5 shows, including assumed permitting fees, the total surveyed soft costs are $23 \%$ of the total residential system price, $17 \%$ of the small commercial system price, and 5\% of the large commercial system price (in 2010). Clearly, economies of scale help reduce these soft costs, particularly installation-labor and permitting costs, for large commercial systems compared with residential and small commercial systems. Among the individual surveyed soft-cost categories, customer acquisition and installation labor are the dominant contributors, while PII and labor for arranging third-party financing contribute relatively little cost. Thus, among the select costs analyzed in this report, customer acquisition and installation labor present the greatest potential for cost reductions for residential and commercial PV systems. 
The SunShot Initiative aims to reduce the installed-system price contribution of all soft costs to approximately $\$ 0.65 / \mathrm{W}$ for residential systems and $\$ 0.44 / \mathrm{W}$ for commercial systems by 2020 (DOE 2012). ${ }^{14}$ Our surveyed soft costs alone (including assumed permitting fees) contribute $\$ 1.50 / \mathrm{W}$ for residential systems, $\$ 0.99 / \mathrm{W}$ for small commercial systems, and $\$ 0.25 / \mathrm{W}$ for large commercial systems. Additional soft costs we did not survey (e.g., installer profit, overhead, financing, and contracting) are significant and would add to these figures. Thus, our survey results provide a partial benchmark for measuring progress over the next decade toward achieving the SunShot soft-cost-reduction targets.

Our ongoing and future work will expand on both the comprehensiveness and accuracy of PV soft-cost analysis, thus enabling a more complete understanding of soft costs and providing dataderived metrics in support of private and public soft-cost-reduction efforts. For example, PV system financing is a poorly understood soft cost. As discussed in Sections 4.2.4 and 5.2.4, residential and commercial PV financing is complex and vital to enabling large-scale PV deployment. We are working to enable a better understanding of PV-financing strategies and their impacts on PV system prices and to develop benchmarks for tracking reductions in financing costs.

As another example, customer-acquisition costs are increased by potential PV customers' lack of access to credible, standardized PV performance data and by installers' need to visit potential PV sites to develop preliminary system designs and prepare bids. Future work in these areas could include benchmarking the specific cost contributions of these barriers and estimating the costreduction potential of solutions such as web-based dissemination of third-party-verified PV consumer data and remote PV site assessment.

As Germany's experience has shown, streamlining the PII process for PV systems is also an important cost-reduction strategy. Analyzing the cost impacts of various PII reforms in U.S. jurisdictions - and disseminating information about effective strategies - could enable relatively rapid soft-cost reductions. In addition, strategies for reducing installation-labor costs are critically important, such as the development of "plug and play" PV systems and widespread implementation of PV installer training and certification programs. Developing more accurate, granular analysis of installation-labor costs would enable the effectiveness of such strategies to be evaluated and optimized.

Finally, understanding the location-dependent variability of soft costs throughout the United States is important. Our future work will seek to expand both the geographic scope of our softcost analysis and the geographic specificity of the results.

Soft costs are both a major challenge and a major opportunity for reducing PV system prices and stimulating SunShot-level PV deployment in the United States. The data and analysis in this report are a first step toward the more detailed understanding of PV soft costs required to track and accelerate these price reductions.

\footnotetext{
${ }^{14}$ The SunShot Initiative's total installed price targets are $\$ 1.50 / \mathrm{W}$ for residential systems and $\$ 1.25 / \mathrm{W}$ for commercial systems.
} 


\section{References}

Barbose, G.; Darghouth, N.; Wiser, R. (2011). Tracking the Sun IV: An Historical Summary of the Installed Cost of Photovoltaics in the United States from 1998 to 2010. Berkeley, CA: Lawrence Berkeley National Laboratory. http://eetd.lbl.gov/ea/emp/reports/lbnl-5047e.pdf

Bony, L; Doig, S.; Hart, C.; Maurer, E.; Newman, S. (2010). Achieving Low-Cost Solar PV: Industry Workshop Recommendations for Near-Term Balance of System Cost Reductions. Snowmass, CO: Rocky Mountain Institute. http://www.rmi.org/KnowledgeCenter/Library/2010-19 BalanceOfSystemReport.

Brooks, B. (2011). Expedited Permit Process for PV Systems: A Standardized Process for the Review of Small-Scale PV Systems. Solar America Board for Codes and Standards Report. http://www.solarabcs.org/permitting.

DOE (U.S. Department of Energy). (2012). SunShot Vision Study. DOE/GO-102012-3037. Washington, DC: U.S. Department of Energy. http://www1.eere.energy.gov/solar/pdfs/47927.pdf.

Goodrich, A. (2012). Personal Communication, May 2012. Golden, CO: National Renewable Energy Laboratory.

Goodrich, A.; James, T.; Woodhouse, M. (2012). Residential, Commercial, and Utility-Scale Photovoltaic System Prices in the United States: Current Drivers and Cost Reduction Opportunities. NREL/TP-6A20-53347. Golden, CO: National Renewable Energy Laboratory.

Langen, C. (2010). "Complexity Cost and Economies of Scale: Why Residential Customers in Germany Pay 25\% Less for a PV System that U.S. Customers." Proceedings of Solar Power International. Washington, DC: Solar Energy Industries Association.

Mills, C.; Newick, K. (2011). Solar Electric Permit Fees in Northern California: A Comparative Study. San Francisco, CA: Sierra Club (first published in 2005).

Pitt, D. (2008). Taking the Red Tape Out of Green Power: How to Overcome the Permitting Obstacles to Small Scale Distributed Renewable Energy. New York, NY: Network for New Energy Choices.

Rocky Mountain Institute (RMI). (2012). Personal communication with RMI experts. October 2012.

Rose, J.; Chapman, S.; Rose, G.; Jackson, R.; Weidman, J.; Christopher, K.; Culley, T.; Keyes, J.; Fox, K.; Varnado, L. (2011). Freeing the Grid: Best Practices in State Net Metering Policies and Interconnection Procedures. New York, NY: Network for New Energy Choices. http://www.newenergychoices.org/uploads/FreeingTheGrid2010.pdf.

RSMeans. (2010). Building Construction Cost Data. Norwell, MA: Reed Construction Data.

Sun Run (2011). The Impact of Local Permitting on Solar Cost. San Francisco, CA: Sun Run. 
U.S. Bureau of Labor Statistics (2011). Occupational Employment Statistics: National Occupational Employment and Wage Estimates. Washington, DC: U.S. Bureau of Labor Statistics. http://www.bls.gov/oes/current/oes_nat.htm\#13-0000.

Varnado, L.; Sheehan, M. (2009). Connecting to the Grid Guide, $6^{\text {th }}$ Edition. Latham, NY: Interstate Renewable Energy Council.

Vote Solar (2011). Project Permit Interactive Permitting Map. http://votesolar.org/cityinitiatives/project-permit/. Accessed June 2012. 


\section{Appendix A: Survey Instrument}

We surveyed installers via an online Qualtrics survey, which dynamically performed calculations (averages, sums, etc.) for the quantitative questions (the survey was scripted in Microsoft Excel). Figure 4 shows a screen capture from the actual online survey. This appendix summarizes the information requested on the survey. Two almost-identical surveys were administered, one for residential installers and one for commercial installers, the only difference being exchanging the words "residential" and "commercial." To eliminate repetitiveness, only the residential survey instructions and questions are extracted here.

\footnotetext{
Section C : Permitting, Inspection, and Interconnection (Questions 10 through 12)

Enter whole numbers only, no commas or decimals.
}

10) On average in 2010, how many labor hours per residential PV installation (both full time employees and contract labor) were spent on the following?

\begin{tabular}{|c|c|}
\hline & $\begin{array}{l}\text { Labor } \\
\text { Hours per } \\
\text { Install }\end{array}$ \\
\hline & $\begin{array}{l}\text { (Enter } \\
\text { number } \\
\text { only) }\end{array}$ \\
\hline $\begin{array}{l}\text { a) preparing a permit package (including } \\
\text { determining a jurisdiction's permitting } \\
\text { requirements, travel time to and from } \\
\text { site/verification, drawing system plans, structural } \\
\text { calculations, zoning application, and delays) }\end{array}$ & \\
\hline $\begin{array}{l}\text { b) submitting the permit package (including } \\
\text { travel time to and from the permitting office and } \\
\text { wait time at the permitting office) }\end{array}$ & \\
\hline $\begin{array}{l}\text { c) completing the permitting inspection } \\
\text { (including paperwork, travel time to and from the } \\
\text { site, wait time for inspector, and physical } \\
\text { inspection) }\end{array}$ & \\
\hline
\end{tabular}

Figure 14. Example online survey question

\section{Summary of Survey Sent to Residential Installers}

Introduction - The objective of this national survey is to benchmark the current process and business soft costs (the costs of red-tape, non-hardware, excess overhead, and delays) associated with deploying photovoltaic (PV) systems. With a focus on residential- and commercial-scale PV systems, this survey will be used to track progress in cost reductions over time in the following areas of process and business soft costs: 1) customer acquisition; 2) permitting, inspection, and interconnection; 3) financing and contracting; and 4) installation and performance.

Instructions: please provide the following information, by placing your responses in the shaded cells. When reporting labor-hour information, answers to each question sum to the total labor hours used (in each section).

\section{Company Profile (Contact information)}

[Respondent is prompted to enter company contact information] 


\section{Section A: Number of PV Systems Installed and Cost Breakdown (Questions 1 through 3)}

1) For the following customer segments, please provide the number of PV systems installed in 2010 and the number of total megawatts installed in 2010:

- Residential

- Commercial

- Other (such as utility-scale and off-grid installations)

- Total

2a) What was the average installed cost (not end consumer price) of residential systems completed in 2010? (in $\$ / \mathrm{W}$ )

2b) What was the average end consumer price of residential systems completed in 2010? (in $\$ / \mathrm{W})$

3) Of the total installed cost above, what percentage was attributable to each of the following cost categories? (totals must add to $100 \%$ )

- Modules

- Inverter

- Other hardware and materials (racking, wiring, etc.)

- Process and business soft costs [including 1) customer acquisition; 2) permitting, inspection and interconnection; 3) financing and contracting; and 4) installation and performance]

\section{Section B: Customer Acquisition}

4) How many bids did you prepare in 2010 , or prior, for residential systems with a planned installation date in 2010? (number of individual bids that could lead to a contract, including multiple bids prepared for the same customer)

5) What was the total cost of residential customer acquisition activities in 2010 (including sales calls, site visits, travel time to and from the site, contract negotiation with system host/owner, and bid/pro-forma preparation, but excluding marketing/advertising and system design)?

6) For residential PV systems, what was the total marketing and advertising budget in 2010 ? (please provide an estimate for the residential sector only if internal accounting combines marketing/advertising budget for residential and commercial systems)

7) What was the total cost of system design in 2010 ? (includes all system design activities both before and after the contract is signed)

8) What technologies do you use in customer acquisition, system design, and bid preparation (including, but not limited to, satellite imaging and web based tools)?

9) In 2010, what percentage of projects with executed contracts were ultimately cancelled? 


\section{Section C: Permitting, Inspection, and Interconnection}

10) On average in 2010, how many labor hours per residential PV installation (both full time employees and contract labor) were spent on the following?

10a) Preparing a permit package (including determining a jurisdiction's permitting requirements, travel time to site/verification, drawing system plans, structural calculations, zoning application, and delays)

10b) Submitting the permit package (including travel time to and from the permitting office and wait time at the permitting office)

10c) Completing the permitting inspection (including paperwork, travel time to and from the site, wait time for inspector, and physical inspection)

10d) Completing the interconnection process (including paperwork, travel time to and from the site, wait time for representative from utility, and physical interconnection)

10e) Applying for and receiving all local, state, and federal financial incentives (including determining eligibility, paperwork, travel time to and from the site, wait time for inspector, and physical inspection)

11) Of the residential-scale PV installations you completed in 2010, what percentage of permit applications were submitted via an online platform?

12) Of the residential PV installations you received permits for in 2010, what percentage had additional costs due to local requirements that go beyond what state or national codes require? (for example, designed smaller system due to fire setbacks, unable to install supply side tap, add extra disconnect, labeling, double flashing, extra attachments)

\section{Section D: Financing and Contracting}

13) Do you offer financing to your residential customers? (yes/no)

14) For the total number of residential PV installations you completed in 2010, please provide a percentage breakdown for how they were financed (must add to 100\%).

14a) Direct cash purchase

14b) Installer-assisted financing from commercial bank

14c) Installer-assisted financing from government loan program

14d) Third-party lease agreement

14e) Third-party power purchase agreement 
15) For the financing options listed in question 14, on average in 2010, how many labor hours per residential PV installation (both employees and contract labor) were spent working with the providers of the funds?

15a) Direct cash purchase

15b) Installer-assisted financing from commercial bank

15c) Installer-assisted financing from government loan program

15d) Third-party lease agreements

15e) Third-party power purchase agreements

\section{Section E: Installation and Performance}

16) On average in 2010, please provide the total number of labor hours per residential PV installation (both employees and contract labor) spent on installation (includes installation only, not travel time to and from the site)

17) For the total number of labor hours reported in question 16, what was the percentage breakdown of electrician vs. non-electrician labor hours used in installation per residential PV system in 2010 ?

17a) Electrician labor hours

17b) Non-electrician (installer) labor hours 
This technical report is a joint project of the National Renewable Energy Laboratory (a laboratory of the U.S. Department of Energy, Office of Energy Efficiency and Renewable Energy) and Lawrence Berkeley National Laboratory (a U.S. Department of Energy National Laboratory operated by the University of California). 